\title{
Trophic resource partitioning of two snook fish species (Centropomidae) in tropical estuaries in Brazil as evidenced by stable isotope analysis
}

\author{
Guazzelli Gonzalez Julio 1, ${ }^{*}$, Ménard Frédéric ${ }^{2}$, Le Loc'h François ${ }^{3}$, Agrelli De Andrade Humber ${ }^{1}$, \\ Pontes Viana Andréa ${ }^{1}$, Ferreira Valdimere ${ }^{1}$, Frédou Flávia Lucena ${ }^{1}$, Lira Alex Souza ${ }^{1}$, \\ Munaron Jean-Marie ${ }^{3}$, Frédou Thierry ${ }^{1}$
}

1 Universidade Federal Rural de Pernambuco, UFRPE, Departamento de Recursos Pesqueiros e Aquicultura, Rua Dom Manuel de Medeiros, s/n, Recife, PE. CEP: 52.171-900, Brazil

${ }^{2}$ Aix Marseille Univ, Univ Toulon, CNRS, IRD, MIO, UM110, Marseille, France

${ }^{3}$ IRD, Laboratoire des Sciences de L'Environnement Marin, UMR 6539, CNRS, UBO, IRD, Ifremer, 29280, Plouzané, France

* Corresponding author : Julio Guazzeli Gonzalez, email address : julio.gonzalez@ufrpe.br

\begin{abstract}
:
We investigated the trophic niches and the resource partitioning of two snook species, the common (Centropomus undecimalis) and the fat snook (C. parallelus), in four tropical estuaries of the northeastern Brazil, using stable isotope analyses of carbon $(\delta 13 \mathrm{C})$ and nitrogen $(\delta 15 \mathrm{~N})$. Fish specimens, mainly juveniles, basal resources and a primary consumer were collected in 2015 during dry and rainy seasons in all estuaries, which exhibited differences in system size, geomorphologic shapes, levels of sea access and anthropic pressures. Potential effect of factors like fish body length, estuary and seasonality on isotope ratios were investigated. Positive relationships between the size of fish and $\delta 15 \mathrm{~N}$ values were found, regardless the species. Our results indicated that snooks can be characterized as secondary consumers and have close trophic niches in most estuaries. Trophic overlaps were more pronounced within the largest estuaries (Catuama and Santa Cruz), whereas smaller systems that have restricted connections to the sea presented low isotopic niche overlap between both species (Suape and Sirinhaém). Moreover, a higher variability of $\delta 13 \mathrm{C}$ and $\delta 15 \mathrm{~N}$ values in snooks was found in larger estuaries undergoing stronger influences from coastal adjacent waters. Although we were not able to detect clear seasonal effects, greater isotopic overlaps were found during the rainy season. Despite the lack of intrinsic differences in life history traits, both species, dominated by juveniles, shared similar trophic niches in these environments.
\end{abstract}




\section{Highlights}

$-\delta^{13} \mathrm{C}$ and $\delta^{15} \mathrm{~N}$ of two Centropomidae were investigated in four estuaries in Brazil. Juveniles of Centropomus undecimalis and C. parallelus have close isotopic niches. Trophic overlaps were more pronounced in large estuaries. Resource partitioning process might reflects the resource availability in estuaries.

Keywords : Brackish water fish, Trophic relationships, Carbon, Nitrogen, Centropomus. 


\section{Introduction}

A theoretical niche is defined as the volume occupied by species in an $n$-dimensional space and predicts that two species cannot coexist when exhibiting the same fundamental niche (Hutchinson, 1957; Odum, 1976). Functionally related species thus tend to exhibit partitioning in resource use on a spatial, temporal or trophic axis to avoid competition and to optimize energy acquisition (Schoener 1974). The trophic niche of a species is one of the quantifiable dimensions of the many facets shaping the niche concept and is perhaps the most studied. Investigating the different resources consumed by different species along with associated levels of availability and accessibility allows for the comprehension of resource use in a fish community and reasons for varying degrees of niche overlapping (Losos, 2000) especially when dealing with important marine resources such as fish of the Centropomidae family (Figueiredo and Menezes, 1980; Muller et al., 2015) in tropical ecosystems.

Snooks (Centropomus spp.) are predators of great economic value used in recreational and commercial fisheries in tropical and subtropical estuaries throughout the American continent (Orrell, 2002; Muller et al., 2015). Among the six sympatric species occurring in the western Atlantic Ocean, the common (Centropomus undecimalis (Bloch, 1792)) and fat snook (Centropomus parallelus (Poey, 1986)) can be distinguished from other species from their greater economic value, larger size and broader and more abundant distributions along estuarine areas in Brazil (Figueiredo and Menezes, 1980; Rivas, 1986). Snooks are euryhaline and estuarine-dependent species that exhibit complex patterns of habitat shifting over their life cycle, forming a mosaic of estuarine and nearshore habitats (Barbour and Adams, 2012; Barbour et al., 2014; Dantas and Barletta, 2016; Daros et al., 2016). Juvenile snooks of both species usually inhabit mangrove creeks and move to deeper brackish waters as they grow (standard lengths of 150 to $300 \mathrm{~mm}$ ) (Stevens et al., 2007; Blewett et al., 2009). In addition, despite differences in the maximum lengths of $C$. undecimalis $(1300 \mathrm{~mm}$; Orrel, 2002) and C. parallelus $(600 \mathrm{~mm}$; Figueiredo and Menezes, 1980), they become adults at very similar sizes (i.e., $\geq 330 \mathrm{~mm}$ for $C$. undecimalis (Peters et al., 1998) and $\geq 280 \mathrm{~mm}$ for $C$. parallelus (Rorigues et al., 2006)). Both species mainly feed on crustaceans and smaller fish (Blewett et al., 2006; Contente et al., 2009; Dutka-Gianelli, 2014; Lira et al., 2017), though fish have been reported to constitute the main source of food for $C$. undecimalis while crustaceans prevail in the $C$. parallelus diet (Aliaume et al., 2005; Lira et al., 2017). The similarities in their habitats 
and feeding habits especially during juvenile stages can lead to resource competition and trophic niche overlapping that may alter the growth of individuals (Aliaume et al., 2005; Dutka-Gianelli, 2014).

The coexistence of the two snook species in tropical estuaries is a natural process, though it is still poorly documented (Dutka-Gianelli, 2014). Studies on Brazilian estuaries are currently restricted to a focus on only a few systems throughout the country and particularly in southern Brazil (Blaber and Barletta, 2016). Further, information regarding the ecological processes of fish often rely on studies conducted at a local scale, and comparisons drawn across sites may thus offer a stronger understanding of habitat use by species in complex environments like estuaries (Stevens et al., 2018). The estuaries addressed in this study exhibit different characteristics in terms of shapes, sizes, food web structures and anthropogenic impacts, which result in differences in how species use resources. For instance, morphological features of estuarine areas (e.g., system size and structural heterogeneity) have been associated with resource availability (Abrantes et al., 2013; Bouillon et al., 2004), fish species diversity and food web composition (França et al., 2012; Vasconcelos et al., 2015), food chain length (Doi et al., 2009) as well as with interspecific processes between functionally related predators (Young, 2001; Mariani et al., 2011). Habitat changes caused by recurrent anthropogenic activities can also influence the environmental boundaries of estuarine systems and their role as migratory corridors for amphidromous species such as snooks (Cianciotto et al., 2019). These changes may affect numerous ecological processes such as the availability of prey from adjacent habitats, species distributions and interspecific processes observed among estuarine predators (Adams et al. 2009; Boucek and Rehage, 2013; Cianciotto et al., 2019). Understanding the coexistence of sympatric predators will help improve ongoing conservation measures and initiate an investigation of potential effects of climate change on the displacement and abundance of estuarine fish (e.g., Araújo et al., 2018).

Trophic niche overlaps can be characterized with stomach content data coupled with other descriptive indexes such as those for diversity and evenness (Bearhop et al., 2004). However, methods for tracing organic matter flux through the food web such as the stable isotope analysis (SIA) method used in this study have provided insightful information on the use and partitioning of resources in fish assemblages (Newsome et al., 2007). Carbon and nitrogen stable isotope analyses offer the advantage of providing time integrated measures on food assimilated by an organism (DeNiro and Epstein, 1978; Herzka, 2005), which may vary from weeks to months (Herzka, 2005; Elsdon et al., 2010), rather than a common snapshot as provided by a dietary analysis (Pinnegar and Polunin, 2000). $\delta^{15} \mathrm{~N}$ exhibits a 
considerable degree of enrichment per trophic level, allowing, with appropriate isotopic baselines and trophic fractionation, for the estimation of the trophic positioning of an organism (Post, 2002; Martínez del Rio et al., 2009). On the other hand, $\delta^{13} \mathrm{C}$ outlines the origins of organic matter (Fry, 2006) when it presents low levels of enrichment across the food web and considerable variability between primary producers (e.g., C3 and C4 plants) (Degens et al., 1968; Smith and Epstein, 1971; Post, 2002).

In this study, we evaluated resource partitioning between $C$. undecimalis and C. parallelus in four tropical estuaries of Brazil. Trophic niches were investigated via carbon $\left(\delta^{13} \mathrm{C}\right)$ and nitrogen $\left(\delta^{15} \mathrm{~N}\right)$ stable isotope analyses to verify whether the use of resources by snook species is affected by estuaries with different morphological and biological features.

\section{Material and methods}

\subsection{Study area and sampling procedures}

Located along the west coast of the South Atlantic Ocean, the study area includes four estuarine systems positioned along the coast of Pernambuco state, northeastern Brazil (Fig. 1), which exhibits distinct morphologic and physicochemical characteristics subject to different anthropogenic pressures (Table 1). The largest estuarine complex in Pernambuco is the Santa Cruz Channel system located along the northern coast, which is characterized as a U-shape channel that connects to the sea through two entrances (Silva et al., 2011). Due to its size and morphological variations (Medeiros and Kjerfve, 1993), the Santa Cruz Channel complex was subdivided in two smaller systems, (1) the estuary of Catuama (Fig. 1a) and (2) the Santa Cruz Channel (Fig. 1b), which are associated with the northern and southern entrances, respectively. The estuaries of (3) Suape and (4) Sirinhaém are distinct in size and shape when compared to those along the northern coast. Suape, located $40 \mathrm{~km}$ from the state capital (Recife), is composed of two main rivers that flow into a large brackish lagoon (CPRH, 2001) (Fig. 1c). In addition to

its limited depth and restricted connection to the ocean, the estuary hosts an important industrial harbor in its marine portion. Sirinhaém, located in the southern part of Pernambuco, is the smallest estuary of the four (Table 1). The system serves as a shallow and narrow connection to the ocean, including a small collection of lagoons and flooded plains (CPRH, 2001) (Fig. 1d).

Sampling surveys were carried out within each estuary from January to April and from August to September of 2015, which represent the local dry and rainy seasons, respectively (Medeiros et al., 2001). Block nets set close to mangrove creeks ( $350 \times 2.9 \mathrm{~m}$, mesh $70 \mathrm{~mm})$ and beach seine trawls $(20 \times 1.9 \mathrm{~m}$, mesh $20 \mathrm{~mm}$ ) were deployed to collect $C$. undecimalis and C. parallelus individuals. All specimens were 
identified from a specific reference (Figueiredo and Menezes, 1980), stored in ice, measured (standard length - SL) and then processed for isotopic analysis.

To identify background isotope ratios for the base of the food web of the studied environment, a long-lived primary consumer (mangrove oyster Crassostrea rhizophorae) and four representative sources of organic matter in estuaries were collected in each survey. Organic matter sources included a few primary producers such as mangrove trees (rotten leaves from Rhizophora mangle) and macroalgae (Sargassum sp. and Ulva sp.) as well as suspended particulate organic matter (POM) and particulate organic matter in sediment (SOM). Oysters and samples of mangrove leaves and macroalgae were collected by hand during low tide periods. POM was sampled while collecting snook specimens by filtering water through fiberglass filters $(0.75 \mu \mathrm{m})$ while SOM was collected from the top $2 \mathrm{~mm}$ layer of sediment.

\subsection{Stable isotope analysis}

White muscle from each fish specimen and the adductor muscles of oysters were extracted, rinsed with distilled water to remove exogenous materials (e.g., remaining scales or bones), and dried in an oven at $60^{\circ} \mathrm{C}$ for 48 hours. The whole sample of basal sources was used for the analysis. Dried samples were ground into a fine powder with a mortar and pestle. POM and SOM samples were duplicated. One subsample was acidified to remove inorganic carbon prior to the $\delta^{13} \mathrm{C}$ analysis. The other subsample was used for our $\delta^{15} \mathrm{~N}$ analysis (Pinnegar and Polunin, 1999). Likewise, lipid extraction was performed on mangrove oyster samples using a procedure adapted from Kojadinovic et al. (2008). Oyster samples were processed in duplicate with one subsample dedicated to $\delta^{13} \mathrm{C}$ and with the other used for lipid extraction for $\delta^{15} \mathrm{~N}$ measurement. Each sample weighed between 0.35 and $0.45 \mathrm{mg}$ and was analyzed for carbon and nitrogen isotope ratios with a mass spectrometer (Thermo Delta V+) coupled to an element analyzer (Thermo Flash 2000, interface Thermo ConFio IV) at the Pôle de Spectrométrie Océan (PSO - IUEM, Plouzané, France).

Results for carbon and nitrogen are reported as $\delta^{13} \mathrm{C}$ and $\delta^{15} \mathrm{~N}$ values, respectively, and are derived from the relation between the isotopic value for the sample and a known standard of $\delta^{13} \mathrm{C}$ or $\delta^{15} \mathrm{~N}=$ $\left[\left(R_{\text {sample }} / R_{\text {standard }}\right)-1\right] \times 10^{3}$ where $R$ corresponds to ratio ${ }^{13} \mathrm{C} /{ }^{12} \mathrm{C}$ or ratio ${ }^{15} \mathrm{~N} /{ }^{14} \mathrm{~N}$. Standards used for $\delta^{13} \mathrm{C}$ and $\delta^{15} \mathrm{~N}$ included PeeDee Belemnite (PDB) limestone and atmospheric nitrogen, respectively. The analytical precision of the analysis monitored from a known standard (Thermo - Acétanilide) every six samples was defined as $\pm 0.11 \%$ o (standard error) and $\pm 0.07 \%$ o for carbon and nitrogen, respectively. 


\subsection{Data analysis}

Due to the broad range of sizes of the snook specimens, we first assessed the relationships between stable isotope values and fish size (SL) using covariance analyses (ANCOVA). We then investigated potential effects of species (C. undecimalis / C. parallelus), estuaries (Catuama / Santa Cruz / Suape / Sirinhaém) and seasons (dry / rainy) using two linear models applying fish length as a continuous explanatory variable and with $\delta^{15} \mathrm{~N}$ and $\delta^{13} \mathrm{C}$ as used dependent variables, respectively. Model selection was performed using classical statistical inference (test F) combined with an automated stepwise selection method based on the Akaike Information Criterion (AIC) (Akaike, 1974). Main effects and first order interactions were evaluated to find the more parsimonious model. Moreover, $\delta^{13} \mathrm{C}$ and $\delta^{15} \mathrm{~N}$ values of oyster and basal sources were tested across the estuaries and seasons using separate non-parametric Kruskal Wallis tests to verify whether differences in isotope ratios observed among the sites are associated with food webs.

Resource partitioning was investigated by analyzing overlaps between the isotopic niches. Isotopic niches of both snook species for each estuary and season were computed with the standard ellipses area method and from $\delta^{13} \mathrm{C}$ and $\delta^{15} \mathrm{~N}$ values. The standard ellipses area (SEA) represents the mean core of the isotopic niche and covers approximately $40 \%$ of the available data (Jackson et al., 2011). This method is less sensitive to sample sizes than other conventional methods (e.g., convex hull area) (Jackson et al., 2011; Syväranta et al., 2013). To address biases that can emerge from comparisons drawn between groups of unequal sample sizes (i.e., underestimation of the population's SEA for small samples), Jackson et al. (2011) proposed a corrected standard ellipse area $\left(\mathrm{SEA}_{\mathrm{C}}\right)$ that maintains the same geometric features but with a slight increase in the ellipse area for smaller sample sizes. In addition, for comparative purposes, the isotopic space was standardized following Cucherousset and Villéger (2015). Finally, to overcome the effect of fish size for nitrogen isotopes, we predicted $\delta^{15} \mathrm{~N}$ values from the selected linear model by fixing fish size at $200 \mathrm{~mm} \mathrm{SL}$, roughly representing the mean and mode of the specimens analyzed. The variability in $\delta^{15} \mathrm{~N}$ among individuals was determined by adding the model's residuals for the given length of each specimen to the predicted $\delta^{15} \mathrm{~N}$ calculated for a fish size of $200 \mathrm{~mm}$. For example, when a residual of 0.25 (positive) was calculated for a $150 \mathrm{~mm}$ (SL) fish of one species for a given estuary and month and when predictions for the same species, estuary and month for a fixed fish size of $200 \mathrm{~mm}$ were measured as $10 \%$, the final predicted $\delta^{15} \mathrm{~N}$ value was defined as $10.25 \%$ o $(10 \%$ o $+0.25 \%$ ). Therefore, 
predicted $\delta^{15} \mathrm{~N}$ and raw $\delta^{13} \mathrm{C}$ values were used to compute standard ellipses, as fish size was not found to have a significant effect on carbon values.

The trophic positioning of snooks across estuaries and seasons was determined using the following formula developed by Post (2002):

$$
\mathrm{TP}_{\text {SIA }}=\left\lfloor\left(\delta^{15} \mathrm{~N}_{\text {consumer }}-\delta^{15} \mathrm{~N}_{\text {baseline }}\right) / \mathrm{TDF}\right\rfloor+\mathrm{TP}_{\text {baseline }}
$$

where $\delta^{15} \mathrm{~N}_{\text {consumer }}$ and $\delta^{15} \mathrm{~N}_{\text {baseline }}$ are the $\delta^{15} \mathrm{~N}$ values for the target consumer and baseline, respectively; $\mathrm{TDF}$ is the trophic discrimination factor and $\mathrm{TP}_{\text {baseline }}$ is the trophic position of the baseline. The trophic position estimate is influenced by the baseline's representativeness of the target consumer food chain (Post, 2002). Therefore, we propose two alternatives approaches to $\mathrm{TP}_{\mathrm{SIA}}$ estimation based on distinct baselines: (i.) $\mathrm{TP}_{\mathrm{SIAl}}-\mathrm{a}$ long-lived filter feeder as a baseline (Crassostrea rhizophorae; $\mathrm{TP}_{\text {baseline }}=2$ ); (ii.) $\mathrm{TP}_{\mathrm{SIA} 2}-\delta^{15} \mathrm{~N}$ the values of all available basal resources of each site as a baseline $\left(\mathrm{TP}_{\text {baseline }}=1\right)$. To account for uncertainty associated with the index, a Bayesian model was applied in the calculation of $\mathrm{TP}_{\text {SIA }}$ using predicted $\delta^{15} \mathrm{~N}$ values of snooks and a TDF of $2.30 \pm 1.60 \%$ (mean \pm standard deviation, McCutchan Jr et al. (2003)).

To draw comparisons, trophic positions were also estimated using stomach content data $\left(\mathrm{TP}_{\mathrm{SCA}}\right)$ from Lira et al. (2017), who studied the feeding habits of snooks of the Santa Cruz and Sirinhaém estuaries. $\mathrm{TP}_{\mathrm{SCA}}$ was determined based on the dietary features of individuals of 150 to $250 \mathrm{~mm}$ (SL, Supplementary Table S1) applying the following formula:

$$
\mathrm{TP}_{\mathrm{SCA}}=\sum\left(W_{\mathrm{i}} T_{\mathrm{i}}\right)+1
$$

where $W_{\mathrm{i}}$ and $T_{\mathrm{i}}$ are the relative weight and the trophic positioning of the $i$ th prey item, respectively (adapted from Winemiller (1990)). $W_{\mathrm{i}}$ is the weight of prey $i$ divided by the total weight of prey items. Trophic positions of prey items were obtained from major functional groups (e.g., primary producers $=1$; omnivorous $=2.5$ ) based on a dietary analysis (Supplementary Table S2). Items with less accurate taxonomic identification (e.g., decapod crustaceans) were considered omnivorous due the diverse feeding habits of each group (Fauchald and Jumars, 1979; Brusca and Brusca, 2007). Fish items were classified by their functional trophic guilds according to Elliott et al. (2007).

All statistical analyses were performed with R version 3.4.4 (R Core Team, 2018) using packages SIAR ("Stable Isotope Analysis in R" (Parnell and Jackson, 2015)) and SIBER ("Stable Isotope Bayesian Ellipses in R" (Jackson and Parnell, 2016)) for the estimation of isotopic niche areas and overlaps, and the 
tRophicPosition ("tRophicPosition: Bayesian Trophic Position Calculation with Stable Isotopes" package (Quezada-Romegialli et al., 2017)) was used for trophic positioning calculations.

\section{Results}

A total of 138 fish specimens (62 C. undecimalis and 76 C. parallelus), 25 mangrove oysters (Crassostrea rhizophorae) and 85 samples of basal sources (22 samples of Rhizophorae mangle, 9 Sargassum sp., 9 Ulva sp., 21 POM and 24 SOM) were collected for stable isotope analyses. Fish sizes ranged from 57 to $392 \mathrm{~mm}$ (SL) with a predominance of juveniles of size classes 150 to $250 \mathrm{~mm}$ (Fig. 2). Stable isotope ratios of the snooks covered a broad range of $\delta^{13} \mathrm{C}\left(-25.38\right.$ to $-14.22 \%$ ) and $\delta^{15} \mathrm{~N}$ values (6.93 to $13.63 \%$ ) across the sites and seasons (Table 2). Stable isotope ratios of oysters and basal resources ranged from -29.24 to $-14.50 \%$ and from -1.03 to $10.11 \%$ o for $\delta^{13} \mathrm{C}$ and $\delta^{15} \mathrm{~N}$, respectively (Supplementary Table S3).

While we find no strong evidence for rejecting the fact that the medians of $\delta^{13} \mathrm{C}$ ratios from basal sources were similar between the studied locations (Kruskal-Wallis: $\chi^{2}=1.471, p$-value $\left.=0.688\right)$ and seasons (Kruskal-Wallis: $\chi^{2}=0.793, p$-value $=0.373$ ), Sirinhaém and Suape exhibited broader levels of variability for $\delta^{13} \mathrm{C}$ than Catuama and Santa Cruz. Mangrove trees and macroalgae were found to be responsible for depleted and enriched $\delta^{13} \mathrm{C}$ values, respectively (Supplementary Table S3). The medians of carbon values for mangrove oysters were found to be similar between seasons (Kruskal-Wallis: $\chi^{2}=$ 0.665, $p$-value $=0.414)$ but not between estuaries $\left(\right.$ Kruskal-Wallis: $\chi^{2}=15.726, p$-value $\left.=0.001\right)$. Conversely, oyster mean $\delta^{15} \mathrm{~N}$ values showed significant differences between seasons (Kruskal-Wallis: $\chi^{2}$ $=14.086, p$-value $<0.001)$ but not between locations (Kruskal-Wallis: $\chi^{2}=4.795, p$-value $=0.187$ ). No significant differences were found in medians of $\delta^{15} \mathrm{~N}$ values from basal resources across the studied locations (Kruskal-Wallis: $\chi^{2}=1.167, p$-value $\left.=0.760\right)$ and seasons $\left(\right.$ Kruskal-Wallis: $\chi^{2}=0.044, p$-value $=0.832$ ). Stable isotope ratios of POM and macroalgae presented the highest values of $\delta^{15} \mathrm{~N}$ for the studied locations and exhibited notably high $\delta^{15} \mathrm{~N}$ means in Suape during the dry season.

The results of the ANCOVA model for snook $\delta^{15} \mathrm{~N}$ values show a significant effect of fish length (adjusted $r^{2}=0.32, F=22.45, p<0.001$ ) with no separate slopes ( $\mathrm{t}$ test, $t=0.376, p=0.707$ ) or distinct intercepts ( $\mathrm{t}$ test, $t=-1.054, p=0.294$ ) for the interaction between length and species. Conversely, fish body length did not influence $\delta^{13} \mathrm{C}$ values (adjusted $r^{2}=0.00, F=1.364, p=0.256$ ) (Fig. 3 ).

The more parsimonious linear model selected for snook $\delta^{15} \mathrm{~N}$ considered species, estuaries, seasons, the covariate size, and interactions between species and estuaries (adjusted $r^{2}=0.53, F=18.69$, 
$p<0.001$; Supplementary Table S4). Residuals were graphically checked for statistical adequacy (Supplementary Fig. S1). Species within each estuary and for a given season showed overall distinct predicted $\delta^{15} \mathrm{~N}$ means with differences ranging from 0.20 to $1.33 \%$. The two snook species exhibited similar predicted $\delta^{15} \mathrm{~N}$ means for Catuama while differences by species were higher in Suape $(0.95$ and $1.05 \%$ during the dry and rainy seasons, respectively) and Sirinhaém (0.85 and $0.41 \%$ ) (Fig. 4). In Santa Cruz, differences in predicted $\delta^{15} \mathrm{~N}$ means were mainly identified by species (1.23 and $1.33 \%$ during dry and rainy seasons, respectively), but snooks also presented more variability and degrees of overlap in predicted $\delta^{15} \mathrm{~N}$ values in this estuary. Differences in predicted $\delta^{15} \mathrm{~N}$ means across seasons were found to be higher for Sirinhaém (0.64 and 1.08\% for C. undecimalis and C. parallelus, respectively) (Fig. 4). Furthermore, predicted $\delta^{15} \mathrm{~N}$ means were higher during the dry season, and C. parallelus presented higher predicted $\delta^{15} \mathrm{~N}$ means than $C$. undecimalis in every estuary other than that in Suape.

Variability in snook $\delta^{13} \mathrm{C}$ values was found to be high, but estuaries were the only significant factor selected under the more parsimonious linear model (adjusted $r^{2}=0.17, F=10.53, p<0.001$; Supplementary Table S4). No pattern was observed between the two species or across seasons (Fig. 4). Overall, mean $\delta^{13} \mathrm{C}$ values for snooks were more depleted in Sirinhaém, and $\delta^{13} \mathrm{C}$ value ranges were found to be greater in Santa Cruz and Catuama (Fig. 4).

The isotopic niches of both snook species were found to vary across areas and seasons (Supplementary Table S5). The estimated standard ellipse area (SEA ${ }_{C}$ ) of snook communities is larger in the northern areas (Santa Cruz and Catuama) than in the southern estuaries (Sirinhaém and Suape) (Fig. 5). Northern estuaries also show more pronounced overlapping patterns than the other systems (Supplementary Table S5). SEA $A_{C}$ overlaps between species were found in all estuaries but that in Suape. No overlap was observed for Sirinhaém for the dry season. Overlaps were found to be more pronounced during the rainy season (Supplementary Table S5, Fig. 5). The SEA ${ }_{C}$ of C. undecimalis in Suape for the rainy season was not computed due to its small sample size $(n=3)$.

Overall, snook species were classified across the third and fourth trophic positions (Table 3). Minor differences were found between species within the sites where $C$. parallelus presented higher $\mathrm{TP}_{\text {SIA }}$ values in all estuaries except in the case of Suape. C. parallelus present the highest $\mathrm{TP}_{\mathrm{SIA}}$ values in Sirinhaém. Seasonal effects on $\mathrm{TP}_{\text {SIA }}$ were found to be weak yet present in Sirinhaém for $\mathrm{TP}_{\text {SIA1 }}$ and in Catuama for $\mathrm{TP}_{\mathrm{SIA} 2}$ where snooks show decreasing values from the dry to rainy seasons $(\sim 0.8)$. $\mathrm{TP}_{\text {SIA1 }}$ shows more pronounced and constant seasonal effects than $\mathrm{TP}_{\text {SIA2 }}$. $\mathrm{TP}_{\text {SIA1 }}$ presents lower modes than 
$\mathrm{TP}_{\mathrm{SIA} 2}$ except for Santa Cruz and Suape during the dry season. $\mathrm{TP}_{\mathrm{SCA}}$ estimates exhibit similar values for snooks in Santa Cruz and Sirinhaém, characterizing snooks as secondary consumers (Table 3).

\section{Discussion}

Trophic niche width and resource partitioning can be expressed with gut content analyses, but stable isotope ratios of nitrogen and carbon are also an efficient tool for elucidating trophic interactions occurring in food webs and between species in competitive environments (e.g., Newsome et al., 2007). We thus attempt to examine hypotheses supported by our results while applying a complementary stable isotope and stomach content methods.

Body size plays a central role in predator-prey interactions (Shelton et al., 1977). The relationship between snook body length and $\delta^{15} \mathrm{~N}$ shows that $C$. undecimalis and $C$. parallelus feed on prey with higher $\delta^{15} \mathrm{~N}$ values as their body length and mouth's gap grow. On average, fish of $300 \mathrm{~mm}$ in length present $\delta^{15} \mathrm{~N}$ values $1.7 \%$ greater than those of specimens of $100 \mathrm{~mm}$ in length, which corresponds to almost one trophic level when assuming a trophic mean $\delta^{15} \mathrm{~N}$ fractionation value of 2.3\% (McCutchan Jr et al., 2003). Our finding confirms previous stomach content and behavioral studies revealing an ontogenetic shift in snook diets (Blewett et al., 2006; Contente et al., 2009; Araújo et al., 2011). Moreover, we were not able to distinguish any species effect for $\delta^{15} \mathrm{~N}$ body length relationships, showing that both species exhibit the same feeding patterns for the size range studied even though $C$. undecimalis presents a faster body growth rate and reaches larger body sizes than C. parallelus (Orrel, 2002; Viana et al., 2016).

Snook $\delta^{13} \mathrm{C}$ values were not found to be impacted by body length while values varied from $25.38 \%$ to $-14.22 \%$. This great variability in $\delta^{13} \mathrm{C}$ values may be due to the wide range of carbon sources in the studied estuaries (Layman, 2007), which may propagate along the food web to snook species. $\delta^{13} \mathrm{C}$ values from basal sources collected in this study ranged from -29.25 to $-14.50 \%$, which are similar to carbon source values reported for other Brazilian estuaries (Garcia et al., 2007; Giarrizzo et al., 2011; Hoeinghaus et al., 2011; Claudino et al., 2015).

The regression models show that the estuaries significantly differ in terms of carbon and nitrogen isotopes, though no differences in mean $\delta^{15} \mathrm{~N}$ and $\delta^{13} \mathrm{C}$ values of basal sources were found between the locations. Thus, snooks exhibited different sources of primary production and feeding strategies that may be associated with differences in system sizes, geomorphologic shapes, levels of sea access and anthropic pressure levels among estuaries. The type of estuary considered and its underlying dynamics determine 
nutrient availability (Bouillon et al., 2004; Lugendo et al., 2007; Hoeinghaus et al., 2011). For example, the estuarine complex of the Santa Cruz Channel (the Santa Cruz and Catuama estuaries) is influenced by marine inputs due to its broad connection to the sea (Flores Montes et al., 1998; Figueiredo et al., 2006). Indeed, marine basal sources often show ${ }^{13} \mathrm{C}$-enriched values when compared to estuarine and freshwater environments (e.g., marine phytoplankton $\delta^{13} \mathrm{C}$ range: -17 to $-23 \%$ (Bouillon et al., 2008)). Therefore, the broader connections of the Santa Cruz Channel compared to those of Sirinhaém and Suape (see Table 1) along with a stronger influence of adjacent coastal waters than that observed in Catuama (Flores Montes et al., 1998; Figueiredo et al., 2006) could explain the broader range of $\delta^{13} \mathrm{C}$ snook values found in Santa Cruz. On the other hand, Sirinhaém presents depleted $\delta^{13} \mathrm{C}$ values that may be due to the estuary's small size and to its narrow connection to the sea, which likely contributes to a low intake of marine water and to an increased assimilation of autochthon ${ }^{13} \mathrm{C}$-depleted primary production (Bouillon et al., 2004). In the midterm, Suape is moderate in size among the estuaries studied with similar characteristics to those observed in Sirinhaém in terms of species diversity levels (Merigot et al., 2016) and morphology structures (Silva et al., 2011). However, the influence of marine water in Suape is more pronounced due to brackish lagoon formations (Paranaguá, 1986; Muniz et al., 2005). In addition, Suape is the area most heavily impacted by anthropic activities. Recurrent discharges of agriculture and industrial waste in Suape suggest a higher input of organic nutrients into the system (CPRH, 2001), which may be related to high $\delta^{15} \mathrm{~N}$ values observed in POM during the dry season (McClelland and Valiela, 1998; Morris et al., 2015).

In addition to intersite variability in $\delta^{13} \mathrm{C}$ and $\delta^{15} \mathrm{~N}$ observed, differences in isotope ratios of snooks and basal sources across seasons were found to be more pronounced in Sirinhaém and in Suape to a lesser extent than in the northern estuaries. It is noteworthy that seasonal variations in tropical estuaries are frequently associated with changes in river runoff and with the contributions of terrestrial nutrients to food webs (e.g., Lin et al., 2007; Abrantes et al., 2014), which usually present lower $\delta^{13} \mathrm{C}$ values than estuarine sources (Smith and Epstein, 1971). The intensity of these effects can be mitigated by the morphological characteristics of each system and seems to reflect the balance of nutrients input into the estuary and their transport to the sea (Abrantes et al., 2013, 2014; Bouillon et al., 2004). The smaller systems of Sirinhaém and Suape with narrower connections to the sea may retain terrestrial nutrients in the estuarine area, allowing them to be incorporated into the food web during the rainy season, enhancing the potential importance of freshwater runoff in providing depleted $\delta^{13} \mathrm{C}$ nutrients (terrestrial and $\mathrm{C} 3$ plant 
input) (Smith and Epstein, 1971; Fry, 2006). Conversely, Santa Cruz and Catuama exhibit a well-mixed environment (Leite et al., 2008), and despite a clear seasonal trend reported for theses estuaries (Medeiros and Kjerfve, 1993; Medeiros et al., 2001), we were not able to identify any seasonal variations. Other studies have similarly observed minimal or absent seasonal variations in estuarine food webs (Akin and Winemiller, 2006; Baeta et al., 2009).

In the present study, the two snook species of $C$. parallelus and $C$. undecimalis were characterized as secondary consumers. These results corroborate previous studies focused on diet (Garcia and Giarrizzo, 2014), stable isotope (Giarrizzo et al., 2011; Winemiller et al., 2011) and ecosystem modeling (Rosado-Solórzano and Guzmán del Próo, 1998; Lira et al., 2018). Despite the differences observed in $\delta^{15} \mathrm{~N}$ levels among species within a given estuary, trophic positions presented similar values across species and estimate methods (stable isotopes and stomach content). It is worth noting that stomach content measures may overestimate $\mathrm{TP}$ values relative to $\mathrm{TP}_{\mathrm{SIA}}$ due to difficulties associated with identifying digested prey items along with their respective TP and due to the contributions of indigestible parts (e.g., decapods carapaces) particularly for piscivorous species such as C. undecimalis (Hyslop, 1980; Amezcua et al., 2015). On the other hand, $\mathrm{TP}_{\mathrm{SIA}}$ is influenced by the baseline selected and by the use of an appropriate trophic discriminant factor (Post, 2002; Martínez del Rio et al., 2009). Although the use of a primary consumer as a baseline is recommended (Post, 2002; Mancinelli et al., 2013), in our case, available basal resources yielded results more similar to those of other studies (i.e., TP values higher than 3 in most cases; ((Giarrizzo et al., 2011; Winemiller et al., 2011; Garcia and Giarrizzo, 2014; Lira et al., 2018)). Primary consumers examined in this study (C. rhizophorae) were carefully collected to form a representative baseline of the pelagic food web and to avoid the incorporation of pooled benthonic sources. In addition, our stomach contents analysis shows that snooks forage on prey associated with the substrate (Lira et al., 2018) and that this may not be directly linked to the pelagic food web in the studied estuaries. Pelagic food webs often exhibit higher $\delta^{15} \mathrm{~N}$ ratios than those of benthonic pathways as exemplified by the higher $\delta^{15} \mathrm{~N}$ values of POM observed here and can present underestimated $\mathrm{TP}_{\text {SIA1 }}$ results. Thus, the use of a conjunct of basal resources as a baseline represents a mixture of pelagic and benthic pathways and may reflect the great diversity of sources available in tropical estuaries (Layman 2007). Nevertheless, this approach is centered on rough mean values of all available basal resources, and by selecting particular pool sources as baselines one can overestimate or underestimate the actual trophic positioning of a species. Basal resources also show high levels of interspecific variability and can obscure 
spatial-temporal differences in the baseline when compared to primary consumers (Mancinelli et al., 2013), which may explain the similarities in $\mathrm{TP}_{\mathrm{SIA} 2}$ values observed between seasons. In addition to the inherent bias associated with $\mathrm{TP}_{\mathrm{SCA}}$ and $\mathrm{TP}_{\mathrm{SIA}}$ estimates, a joint approach adopting these methods can provide a more compelling account of the trophic positioning of organisms (e.g., Amezcua et al., 2015).

The isotopic niche approach can be used as a proxy for the diversity of isotopically distinct food sources assimilated by an organism (Newsome et al., 2007). In this study, larger $\mathrm{SEA}_{\mathrm{C}}$ values were observed in Santa Cruz and to a lesser extent in Catuama. Such patterns can be attributed to the availability of resources in the studied locations. Coastal environments encompass a mosaic of habitats that are connected to one another through physical processes and through the movement of transient species (Sheaves, 2009). Broader connections to the sea observed in Santa Cruz and Catuama relative to Suape and Sirinhaém may facilitate connectivity to adjacent habitats and in turn enhance the availability of resources with distinct isotope ratios in these systems. Niche widths can also be influenced by interspecific processes occurring between coexisting species. In this case, we find a negative relationship between interspecific competition and niche breadth (niche variation hypothesis, Van Valen (1965)) where a reduction of interspecific processes is favored among individual variations in the use of resources (Bolnick et al., 2010). Wider isotopic niches observed in Santa Cruz than in Sirinhaém reveal similar trends as those reported by Lira et al. (2017) via stomach content analysis. Although resource availability was not directly examined, a stomach content analysis of snook species caught in Santa Cruz and Sirinhaém revealed that the diet of $C$. parallelus differs across estuaries with higher proportions of decapod crustaceans found in Sirinhaém and with fish and crustaceans prevailing in Santa Cruz (Lira et al., 2017). Such differences in diet and stable isotope analysis results reflect the opportunistic behaviors of $C$. parallelus in an environment with highly available food sources.

Overall, snooks exhibited similar trophic niches. Higher degrees of overlap evidenced from SEA $A_{C}$ values were observed for Santa Cruz and Catuama. Theoretically, the occurrence of functionally related species in an environment with limited resources leads to food partitioning processes (Losos, 2000). Conversely, when resources are abundant, niche overlap (i.e., dietary overlap) between species may not configure interspecific competition but instead the sharing of prey (Delbeek and Williams, 1987; Lucena et al., 2000). Our findings support this hypothesis given similarities in the diets of snook species (Vasconcelos Filho et al., 2003; Lira et al., 2017) and the abundance of gobies (snooks' main prey) found in Santa Cruz (see Merigot et al., 2016; Silva-Júnior et al., 2016). Moreover, Santa Cruz and Catuama 
estuaries show more abundant and taxonomically related fauna than Suape and Sirinhaém estuaries (Merigot et al., 2016) and support a wide range of fish species of the intermediate trophic levels (Vasconcelos Filho et al., 2003; Ferreira, 2018). Broader isotopic niches and greater overlaps observed in Santa Cruz and Catuama suggest that snooks feed on similar sources but also cover a broader food spectrum in these estuaries. By contrast, in smaller estuaries, i.e., Sirinhaém and Suape estuaries, snooks exhibit more pronounced patterns of resource partitioning. Aliaume et al. (2005) reported that juvenile snooks exhibit similar feeding habits in estuarine areas of Porto Rico but are able to switch their prey to minimize competition with other species. Analogously, more pronounced SEA $\mathrm{C}_{\mathrm{C}}$ overlaps between snook species observed during the rainy season may be attributable to a broader availability of prey during this period. For instance, Silva et al. (2003) observed higher densities and less diversity in zooplankton communities in Santa Cruz during the rainy season. Seasonal effects of resource partitioning observed between consumers have also been reported for other fish species and often reflect peak levels of potential prey (e.g., Delbeek and Williams, 1987; Lucena et al., 2000).

Our findings show that mostly juvenile Centropomus parallelus and C. undecimalis have similar trophic niches across the four estuaries studied, though the overall overlap in isotopic niches observed between species does not exceed 30\%. Trophic partitioning between snooks was found to be greater in environments with restricted connection to the sea and with more mangrove area cover. The resource partitioning process observed between the two species likely reflects a relationship between morphologic features and resource availability within each system. Moreover, this potential sharing of resources does not represent a limiting factor for snook populations, as they constitute one of the most abundant species in estuaries of the area (Merigot et al., 2016). These results highlight the capacity for snooks to adapt to environments with different food web compositions, supporting the notion that these predators act as important species in estuarine environments (Lira et al., 2018).

Snooks are important marine resources for local fisherman as sources of income and food. However, in most regions of Brazil, conservation strategies for these species are focused strictly in their minimum catch sizes while the potential effects of habitat degradation on fish populations are often neglected. Habitat modification still remains a relevant threat to estuarine fish and especially for tropical ecosystems in developing countries, where population sizes and demand for resources are constantly increasing (Lotze et al., 2006; FAO, 2018). Indeed, over the last decades, estuaries have faced changes to their environmental features (e.g., freshwater flows, mangrove cover levels, water temperatures, 
sedimentation rates and salinity gradients) due to anthropogenic activities and climate change (Yang, 2015; Pelage et al., 2019). These modifications directly affect the food web dynamics and distribution of snooks species by regulating their accessibility to habitats and the availability of prey (Adams et al., 2009; Araújo et al., 2018; Cianciotto et al., 2019). For instance, human induced changes in the freshwater flow regimes of estuarine creeks in Florida have been shown to decrease the diversity of prey available to snooks (Adams et al., 2009). Moreover, the displacement of estuarine environmental boundaries due to climate change may enhance the coexistence and resource partitioning of snooks and other freshwater or marine species (e.g., Boucek and Rehage (2013), Possamai et al. (2018)). Understanding how snooks use available resources under different scenarios (environmental settings) is of great importance to the evaluation of the ecological role of estuaries and to the elaboration of management policies based on an ecosystem approach rather than based on species-specific strategies for snooks. The results presented in this work exemplify plasticity in snook habitat use and resource partitioning across estuaries more accurately and can serve as a source of reference for future studies focused on the effects of climate change on estuarine fish ecology. While this study focused on juvenile fish, further studies on ontogenetic changes in habitat use by Centropomus parallelus and C. undecimalis might help elucidate patterns of resource partitioning occurring at different life stages among the two species.

\section{Acknowledgements}

This study was funded in part by the INCT (National Institute of Science and Technology, CNPq ${ }^{\circ}$ 610013/2011-4) in Tropical Marine Environments - INCT-AmbTropic, the CNPq (National Council for Scientific and Technological Development, CNPq $n^{\circ} 479845 / 2013-1, n^{\circ} 407125 / 2013-2$ and $n^{\circ}$ 207786/2015-1), and by CAPES (Coordination for the Improvement of Higher Education Personnel) for providing the scholarship to the first author. We thanks to the members of BIOIMPACT Laboratory for their efforts on field campaigns and sampling procedures, to A. Bertrand for personal advices during the preparation of the manuscript and to the anonymous reviewers who helped in the improvement of the work. This article is a contribution to the PADDLE project, which has received funding from the European Union's Horizon 2020 research and innovation programme under grant agreement No 734271, to the LMI TAPIOCA and to the SMAC project (CAPES/COFECUB $n^{\circ} 88881.142689 / 2017-01$ ).

\section{References}

Abrantes, K.G., Barnett, A., Marwick, T.R., Bouillon, S., 2013. Importance of terrestrial subsidies for 
estuarine food webs in contrasting East African catchments. Ecosphere 4, 1-33. doi:10.1890/ES1200322.1

Abrantes, K.G., Johnston, R., Connolly, R.M., Sheaves, M., 2014. Importance of Mangrove Carbon for Aquatic Food Webs in Wet-Dry Tropical Estuaries. Estuaries and Coasts 38, 383-399. doi:10.1007/s12237-014-9817-2

Adams, A.J., Wolfe, R.K., Layman, C.A., 2009. Preliminary Examination of How Human-driven Freshwater Flow Alteration Affects Trophic Ecology of Juvenile Snook (Centropomus undecimalis) in Estuarine Creeks. Estuaries and Coasts 32, 819-828. doi: 10.1007/s12237-009-9156-x

Akaike, H., 1974 A new look at the statistical model identification. IEEE Transactions of Automatic Control AC. 19, 716-723

Akin, S., Winemiller, K.O., 2006. Seasonal Variation in Food Web Composition and Structure in a Temperate Tidal Estuary. Estuaries and Coasts 29, 552-567.

Aliaume, C., Zerbi, A., Miller, J.M., 2005. Juvenile snook species in Puerto Rico estuaries: distribution, abundance and habitat description. Proceedings of the Gulf and Caribbean Fisheries Institute. 47, $499-519$.

Amezcua, F., Muro-Torres, V., Solo-Jiménez, M.F., 2015. Stable isotopes analysis versus TROPH: a comparison of methods for estimating trophic positions in a subtropical estuarine system. Aquatic Ecology 49, 235-250. doi:10.1007/s10452-015-9517-4

Araújo, I.M.S., Silva-Falcão, E.C., Severi, W., 2011. Buccal apparatus and gastrointestinal tract dimensions associated to the diet of early life stages of Centropomus undecimalis (Centropomidae, Actinopterygii). Iheringia Série Zoológica. 101, 85-92.

Araújo, F.G., Teixeira, T.P., Guedes, A.P.P., Azevedo, M.C.C. de, Pessanha, A.L.M., 2018. Shifts in the abundance and distribution of shallow water fish fauna on the southeastern Brazilian coast: a response to climate change. Hydrobiologia 814, 205-218. doi: 10.1007/s10750-018-3537-8

Baeta, A., Pinto, R., Valiela, I., Richard, P., Niquil, N., Marques, J.C., 2009. $\delta^{15} \mathrm{~N}$ and $\delta^{13} \mathrm{C}$ in the Mondego estuary food web: Seasonal variation in producers and consumers. Marine Environmental Research. 67, 109-116. doi:10.1016/j.marenvres.2008.11.005

Barbour, A.B., Adams, A.J., 2012. Biologging to examine multiple life stages of an estuarine-dependent fish. Marine Ecology Progress Series 457, 241-250. doi:10.3354/meps09669

Barbour, A.B., Adams, A.J., Lorenzen, K., 2014. Size-based, seasonal, and multidirectional movements 
of an estuarine fish species in a habitat mosaic. Marine Ecology Progress Series 507, 263-276. doi: $10.3354 /$ meps 10837

Bearhop, S., Adams, C.E., Waldron, S., Fuller, R.A., Macleod, H., 2004. Determining trophic niche width: A novel approach using stable isotope analysis. Journal of Animal Ecology 73, 1007-1012. doi:10.1111/j.0021-8790.2004.00861.x

Blaber, S.J.M., Barletta, M., 2016. A review of estuarine fish research in South America: What has been achieved and what is the future for sustainability and conservation? Journal of Fish Biology 89, 537568. doi:10.1111/jfb. 12875

Blewett, D.A., Stevens, P.W., Champeau, T.R., Taylor, R.G., 2009. Use of rivers by common snook Centropomus undecimalis in Southwest Florida: a first step in addressing the overwintering paradigm. Florida Scientist 72, 310-324.

Blewett, D.A., Hensley, R.A., Stevens, P.W., 2006. Feeding habits of common snook, Centropomus undecimalis, in Charlotte Harbor, Florida. Gulf and Caribbean Research 18, 1-13.

Bolnick, D.I., Ingram, T., Stutz, W.E., Snowberg, L.K., Lau, O.L., Paull, J.S., 2010. Ecological release from interspecific competition leads to decoupled changes in population and individual niche width. Proceedings of the Royal Society B: Biological Sciences 277, 1789-1797. doi:10.1098/rspb.2010.0018

Borges, G.C.P., 2011. Comunidade fitoplanctônica do estuário do Rio Massangana (Pernambuco Brasil). MSc Thesis, Univ. Federal de Pernambuco, Brazil, unpublised.

Boucek, R.E., Rehage, J.S., 2013. No free lunch: displaced marsh consumers regulate a prey subsidy to an estuarine consumer. Oikos 122, 1453-1464. doi: 10.1111/j.1600-0706.2013.20994.x

Bouillon, S., Connolly, R.M., Lee, S.Y., 2008. Organic matter exchange and cycling in mangrove ecosystems: Recent insights from stable isotope studies. Journal of Sea Research 59, 44-58. doi:10.1016/j.seares.2007.05.001

Bouillon, S., Moens, T., Overmeer, I., Koedam, N., Dehairs, F., 2004. Resource utilization patterns of epifauna from mangrove forests with contrasting inputs of local versus imported organic matter. Marine Ecology Progress Series 278, 77-88. doi:10.3354/meps278077

Brusca, R., Brusca, G.J., 2007 Invertebrates, Segunda Edição. Editora Guanabara Koogan S.A., Rio de Janeiro, 968 pp.

Claudino, M.C., Pessanha, A.L.M., Araújo, F.G., Garcia, A.M., 2015. Trophic connectivity and basal 
food sources sustaining tropical aquatic consumers along a mangrove to ocean gradient. Estuarine, Coastal and Shelf Science 167, 45-55. doi:10.1016/j.ecss.2015.07.005

Cianciotto, A.C., Shenker, J.M., Adams, A.J., Rennert, J.J., Heuberger, D., 2019. Modifying mosquito impoundment management to enhance nursery habitat value for juvenile common Snook (Centropomus undecimalis) and Atlantic tarpon (Megalops atlanticus). Environmental Biology of Fishes 102, 403-416. doi: 10.1007/s10641-018-0838-8

Contente, R.F., Stefanoni, M.F., Gadig, O.B.F., 2009. Size-related shifts in dietary composition of Centropomus parallelus (Perciformes: Centropomidae) in an estuarine ecosystem of the southeastern coast of Brazil. Journal of Applied Ichthyology 25, 335-342. doi:10.1111/j.1439-0426.2008.01179.x

CPRH, 2001. Diagnóstico socioambiental do litoral Sul de Pernambuco. Agência Estadual do Meio Ambiente, Recife, 89 pp.

Cucherousset, J., Villéger, S., 2015. Quantifying the multiple facets of trophic diversity: new integrative metrics for stable isotope ecology. Ecological Indicators 56, 152-160.

Dantas, D.V., Barletta, M., 2016. Habitat use by Centropomus undecimalis in a rocky area of estuarine beach in north-east Brazil. Journal of Fish Biology 89, 793-803. doi:10.1111/jfb.13001

Daros, F.A., Spach, H.L., Correia, A.T., 2016. Habitat residency and movement patterns of Centropomus parallelus juveniles in a subtropical estuarine complex. Journal of Fish Biology 88, 1796-1810. doi:10.1111/jfb.12944

Degens, E.T., Behrendt, M., Gotthardt, B., Reppmann, E., 1968. Metabolic fractionation of carbon isotopes in marine plankton-II. Data on samples collected off the coasts of Peru and Ecuador*. Deep Sea Research and Oceanographic Abstrcts 15, 11-20. doi:10.1016/0011-7471(68)90025-9

Delbeek, J.C., Williams, D.D., 1987. Food Resource Partitioning Between Sympatric Populations of Brackishwater Sticklebacks. Journal of Animal Ecology 56, 949-967.

DeNiro, M.J., Epstein, S., 1978. Influence of diet on the distribution of carbon isotopes in animals. Geochimica et Cosmochimica Acta 42, 495-506.

Doi, H., Chang, K.H., Ando, T., Ninomiya, I., Imai, H., Nakano, S.I., 2009. Resource availability and ecosystem size predict food-chain length in pond ecosystems. Oikos 118, 138-144. doi:10.1111/j.1600-0706.2008.17171.x

Dutka-Gianelli, J., 2014. Feeding habits of the smallscale fat snook from East-Central Florida. Transactons of the American Fisheries Society 143, 1199-1203. doi:10.1080/00028487.2014.918056 
Elliott, M., Whitfield, A. K., Potter, I. C., Blaber, S. J. M., Cyrus, D. P., Nordlie, F. G., Harrison, T. D., 2007. The guild approach to categorizing estuarine fish assemblages: A global review. Fish and Fisheries 8, 241-268. doi: 10.1111/j.1467-2679.2007.00253.x

Elsdon, T.S., Ayvazian, S., McMahon, K.W., Thorrold, S.R., 2010. Experimental evaluation of stable isotope fractionation in fish muscle and otoliths. Marine Ecology Progress Series 408, 195-205. doi:10.3354/meps08518

FAO, 2018. The state of world fisheries and aquaculture 2018 - meeting the sustainable development goals. Food and Agriculture Organization, Rome, 210 pp.

Fauchald, K., Jumars, P., 1979. The Diet of Worms: A studie of Polychaete Feeding Gilds. Oceanography and Marine Biology: An annual review 17, 193-284.

Ferreira, V., 2018. Estrutura trófica da ictiofauna estuarina e marinha do complexo Itapissuma/Itamaracá, Norte de Pernambuco. Ph.D Thesis, Univ. Federal Rural de Pernambuco, Brazil, unpublised.

Figueiredo, J.L., Menezes, N.A., 1980. Manual de Peixes Marinhos do Sudeste do Brasil. III. Teleostei (2). Museu de Zoologia, Univiversidade de São Paulo, São Paulo, 90 pp.

Figueiredo, J.A. de, Muniz, K., Macêdo, S.J. de, Flores-Montes, M.J., Feitosa, F.A.N., 2006. Hidrologia e biomassa fitoplanctônica nas Barras Orange e Catuama (Canal De Santa Cruz), em Itamaracá-Pe: variação nictemeral. Arquivos de Ciências do Mar 39, 5-17.

Flores Montes, M.J., Macêdo, S.J. de, Koening, M.L., Lins Correia, I., 1998. Variação nictemeral do fitoplâncton e elementos nutrientes no canal de Santa Cruz, Itamaracá - PE - Brasil. Trabalhos do Instituto Oceanografico da Universidade Federal de Pernambuco 26, 13-26.

França, S., Vasconcelos, R.P., Fonseca, V.F., Tanner, S.E., Reis-Santos, P., Costa, M.J., Cabral, H.N., 2012. Predicting fish community properties within estuaries: Influence of habitat type and other environmental features. Estuarine, Coastal and Shelf Science 107, 22-31. doi:10.1016/j.ecss.2012.04.013

Fry, B., 2006. Stable Isotope Ecology. Springer, New York, 308 pp.

Lotze, H.K., Lenihan, H.S., Bourque, B.J., Bradbury, R.H., Cooke, R.G., Kay, M.C., Kidwell, S.M., Kirby, M.X., Peterson, C.H., Jackson, J.B.C., 2006. Depletion, Degradation, and Recovery Potential of Estuaries and Coastal Seas. Science 312, 1806-1809. doi: 10.1126/science.1128035

Garcia, T.O., Giarrizzo, T., 2014. Nível trófico de peixes da costa brasileira. Biota Amazônia 4, 130-160. doi: 10.18561/2179-5746/biotaamazonia.v4n2p130-160 
Garcia, A.M., Hoeinghaus, D.J., Vieira, J.P., Winemiller, K.O., 2007. Isotopic variation of fishes in freshwater and estuarine zones of a large subtropical coastal lagoon. Estuarine, Coastal and Shelf Science 73, 399-408. doi:10.1016/j.ecss.2007.02.003

Giarrizzo, T., Schwamborn, R., Saint-Paul, U., 2011. Utilization of carbon sources in a northern Brazilian mangrove ecosystem. Estuarine, Coastal and Shelf Science 95, 447-457. doi:10.1016/j.ecss.2011.10.018

Guimarães, A.S., Travassos, P., Souza Filho, P.W.M.E., Gonçalves, F.D., Costa, F., 2010. Impact of aquaculture on mangrove areas in the northern Pernambuco Coast (Brazil) using remote sensing and geographic information system. Aquaculture Research 41, 828-838. doi:10.1111/j.13652109.2009.02360.x

Herzka, S.Z., 2005. Assessing connectivity of estuarine fishes based on stable isotope ratio analysis. Estuarine, Coastal and Shelf Science 64, 58-69. doi:10.1016/j.ecss.2005.02.006

Hoeinghaus, D.J., Vieira, J.P., Costa, C.S., Bemvenuti, C.E., Winemiller, K.O., Garcia, A.M., 2011. Estuary hydrogeomorphology affects carbon sources supporting aquatic consumers within and among ecological guilds. Hydrobiologia 673, 79-92. doi:10.1007/s10750-011-0751-z

Hutchinson, G.E., 1957. Concluding remarks. Cold Spring Harb. Symp. Quantitative Biology 22, 415427. doi:10.1101/SQB.1957.022.01.039

Hyslop, E.J., 1980. Stomach contents analysis - a review of methods and their application. Journal of Fish Biology 17, 411 - 429. doi: 10.1111/j.1095-8649.1980.tb02775.x

Jackson, A.A., Parnell, A., 2016. Package “SIBER” - Stable Isotope Bayesian Ellipses in R. R Package Version 2.0.3.

Jackson, A.L., Inger, R., Parnell, A.C., Bearhop, S., 2011. Comparing isotopic niche widths among and within communities: SIBER - Stable Isotope Bayesian Ellipses in R. Journal of Animal Ecology 80, 595-602. doi:10.1111/j.1365-2656.2011.01806.x

Kojadinovic, J., Richard, P., Le Corre, M., Cosson, R.P., Bustamante, P., 2008. Effects of Lipid Extraction on $\delta^{13} \mathrm{C}$ and $\delta^{15} \mathrm{~N}$ Values in Seabird Muscle, Liver and Feathers. Waterbirds 31, 169-178. doi: 10.1675/1524-4695(2008)31[169:EOLEOC]2.0.CO;2

Layman, C.A., 2007. What can stable isotope ratios reveal about mangroves as fish habitat? Bulletin of Marine Science 80, 513-527.

Leite, F.S., Araújo, M., Medeiros, C., Endres, J.-P., 2008. Energy balance and mixing timescales in a 
stirring tropical estuary, Itamaracá, Brazil. Journal of Coastal Research 24, 151-160. doi:10.2112/040399.1

Lin, H.J., Kao, W.Y., Wang, Y.T., 2007. Analyses of stomach contents and stable isotopes reveal food sources of estuarine detritivorous fish in tropical/subtropical Taiwan. Estuarine, Coastal and Shelf Science 73, 527-537. doi:10.1016/j.ecss.2007.02.013

Lira, A.S., Angelini, R., Le Loc’h, F., Ménard, F., Lacerda, C., Frédou, T., Frédou, F.L., 2018. Trophic flow structure of a neotropical estuary in northeastern Brazil and the comparison of ecosystem model indicators of estuaries. Journal of Marine Systems 182, 31-45. doi:10.1016/j.jmarsys.2018.02.007

Lira, A.S., Frédou, F.L., Viana, A.P., Eduardo, L.N., Frédou, T., 2017. Feeding ecology of Centropomus undecimalis (Bloch, 1792 ) and Centropomus parallelus (Poey, 1860) in two tropical estuaries in Northeastern Brazil. Pan-American Journal of Aquatic Sciences 12, 123-135.

Losos, J.B., 2000. Ecological character displacement and the study of adaptation. Proceedings of the National Academy of Sciences 97, 5693-5695.

Lucena, F.M., Vaske Jr, T., Ellis, J.R., O’Brien, C.M., 2000. Seasonal variation in the diets of bluefish, Pomatomus saltatrix (Pomatomidae) and striped weakfish, Cynoscion guatucupa (Sciaenidae) in southern Brazil: implications of food partitioning. Environmental Biology of Fishes 57, 423-434.

Lugendo, B.R., Nagelkerken, I., Kruitwagen, G., van der Velde, G., Mgaya, Y.D., 2007. Relative importance of mangroves as feeding habitats for fishes; a comparison between mangrove habitats with different settings. Bulletin of Marine Science. 80, 497-512.

Mancinelli, G., Vizzini, S., Mazzola, A., Maci, S., Basset, A., 2013. Cross-validation of $\delta^{15} \mathrm{~N}$ and FishBase estimates of fish trophic position in a Mediterranean lagoon: The importance of the isotopic baseline. Estuarine, Coastal and Shelf Science 135, 77-85. doi:10.1016/j.ecss.2013.04.004

Mariani, S., Boggan, C., Balata, D., 2011. Food resource use in sympatric juvenile plaice and flounder in estuarine habitats. Marine Ecology 32, 96-101. doi:10.1111/j.1439-0485.2010.00419.x

Martínez del Rio, C., Wolf, N., Carleton, S.A., Gannes, L.Z., 2009. Isotopic ecology ten years after a call for more laboratory experiments. Biological Reviews 84, 91-111. doi:10.1111/j.1469185X.2008.00064.X

McClelland, J.W., Valiela, I., 1998. Changes in food web structure under the influence of increased anthropogenic nitrogen inputs to estuaries. Marine Ecology Progress Series 168, 259-271. doi:10.3354/meps168259 
McCutchan Jr, J.H., Lewis Jr, W.M., Kendall, C., McGrath, C.C., 2003. Variation in trophic shift for stable isotope ratios of carbon, nitrogen, and sulfur. Oikos 102, 378-390. doi:10.1034/j.16000706.2003.12098.x

Medeiros, C., Kjerfve, B., 1993. Hydrology of a tropical estuarine system: Itamaracá, Brazil. Estuarine, Coastal and Shelf Science 36, 495-515.

Medeiros, C., Kjerfve, B., Araujo, M., Neumann-Leitão, S., 2001. The Itamaracá Estuarine Ecosystem, Brazil. In: Seeliger, U., Kjerfve, B. (Eds.), Coastal Marine Ecosystem of Latin America (Ecological Studies). Springer, New York, pp. 71-82. doi:10.1007/978-3-662-04482-7

Merigot, B., Lucena Frédou, Flávia Viana, A.P., Ferreira, B.P., Costa Junior, E. do N., Silva-Júnior, C.A.B. da, Frédou, T., 2016. Fish assemblages in tropical estuaries of Northeast Brazil: a multicomponent diversity approach. Ocean and Coastal Management 143, 175-183. doi:10.1016/j.ocecoaman.2016.08.004

Morris, C., Lee, S.Y., van de Merwe, J., 2015. $\delta^{15} \mathrm{~N}$ of estuarine fishes as a quantitative indicator of urbanization. Ecological Indicators. 56, 41-49. doi:10.1016/j.ecolind.2015.03.028

Muller, R.G., Trotter, A.A., Stevens, P.W., 2015. The 2015 stock assessment update of common snook, Centropomus undecimalis. Technical Report, Fish and Wildlife Research Institute, Florida, unpublised.

Muniz, K., Neto, B.B., Macêdo, S.J., Filho, W.C.P., 2005. Hydrological impact of the Port Complex of Suape on the Ipojuca River (Pernambuco-Brazil). Journal of Coastal Research 215, 909-914. doi:10.2112/03-0070.1

Newsome, S.D., Martinez del Rio, C., Bearhop, S., Phillips, D.L., 2007. A Niche for Isotope Ecology. Frontiers in Ecology and the Environment 5, 429-436. doi:10.1890/060150.01

Odum, E.P., 1976. Fundamentals of Ecology. Calouste Gulbenkian Foundation, Lisboa, 823 pp.

Orrell, T.M., 2002. Perciformes. In: Carpenter, K.E. (Eds.), The Living Marine Resources of the Western Central Atlantic, Volume 2: Bony fishes part 1 (Acipenseridae to Grammatidae), Food and Agriculture Organization of the United States, Rome, pp. 1286- 1303

Paranaguá, M.N., 1986. Zooplankton of the Suape Area (Pernambuco - Brazil). Tropical Oceanography $19,113-124$.

Parnell, A.A., Jackson, A., 2015. Package "siar" - Stable Isotope Analysis in R. R Package Version 4.2.

Pelage, L., Domalain, G., Lira, A.S., Travassos, P., Frédou, T., 2019. Coastal land use in Northeast 
Brazil : Mangrove coverage evolution over three decades. Tropical Conservation Science 12, 1-15. doi: $10.1177 / 1940082918822411$

Peters, K.M., Matheson R.E., Matheson, R.E., Jr., Taylor, R.G., 1998. Reproduction and early life history of common snook, Centropomus undecimalis (Bloch), in Florida. Bulletin of Marine Science 62, 509529

Pinnegar, J.K., Polunin, N.V.C., 2000. Contributions of stable-isotope data to elucidating food webs of Mediterranean rocky littoral fishes. Oecologia 122, 399-409. doi:10.1007/s004420050046

Pinnegar, J.K., Polunin, N.V.C., 1999. Differential fractionation of $\delta^{13} \mathrm{C}$ and $\delta^{15} \mathrm{~N}$ among fish tissues: Implications for the study of trophic interactions. Functional Ecology 13, 225-231. doi:10.1046/j.1365-2435.1999.00301.x

Possamai, B., Vieira, J.P., Grimm, A.M., Garcia, A.M., 2018. Temporal variability (1997-2015) of trophic fish guilds and its relationships with El Niño events in a subtropical estuary. Estuarine, Coastal and Shelf Science 202, 145-154. doi: 10.1016/j.ecss.2017.12.019

Post, D.M., 2002. Using stable isotopes to estimate trophic position: models, methos, and assumptions. Ecology 83, 703-718. doi:10.2307/3071875

Quezada-Romegialli, C., Jackson, A.L., Harrod, C., 2017. Package "tRophicPosition" - Bayesian Trophic Position Calculation with Stable Isotopes. R Package Version 0.7.0

R Core Team. 2018. R: a Language and Environment for Statistical Computing.

Rivas, L.R., 1986. Systematic Review of the Perciform Fishes of the Genus Centropomus. American Society of Ichthyologists and Herpetologists 3, 579-611.

Rorigues, P.P., Leite-Jr., N. de O., Martins, A.S., 2006. Fat snook (Centropomus parallelus) reproductive aspects in the Doce river estuary, east coast of Brazil. In: Mees, J., Seys, J. (eds), VLIZ Young Scientists Day. Vliz Special Publication/Book of abstracts. Vlaams Instituut voor de Zee (VLIZ): Oostende, Belgium, pp. 52-52.

Rosado-Solórzano, R., Guzmán del Próo, S., 1998. Preliminary trophic structure model for Tampamachoco lagoon, Veracruz, Mexico. Ecological Modelling 109, 141-154. doi: 10.1016/S0304$3800(98) 00011-8$

Schoener, T.W., 1974. Resource partitioning in ecological communities. Science 185, 27-39. doi: 10.1126/science. 185.4145 .27 
Sheaves, M., 2009. Consequences of ecological connectivity: the coastal ecosystem mosaic. Marine Ecology Progress Series 391, 107-115. doi:10.3354/meps08121

Shelton, R.W., Sutcliffe, W. Jr., Paranjape, M.A. 1977. Structure of pelagic food chain and relationship between plankton and fish production. Journal of the Fisheries Research Board of Canada 34, 23442353.

Silva, J.B. da, Galvíncio, J.D., Corrêa, A.C.B., Silva, D.G. da, Machado, C.C.C., 2011. Classificação geomorfológica dos estuários do Estado de Pernambuco (Brasil) com base em imagens do LANDSAT 5/TM. Revista Brasileira de Geografia Física 1, 118-133.

Silva, M.H. da, 2009. Estrutura e produtividade da comunidade fitoplanctônica de um estuário tropical (Sirinhaém, Pernambuco, Brasil). Ph.D Thesis, Univ. Federal de Pernambuco, Brazil, unpublised.

Silva, T. de .A. e, Neumann-Leitão, S., Schwamborn, R., Gusmão, M.L. de O., Nascimento-Vieira, D.A. do, 2003. Diel and seasonal changes in the macrozooplankton community of a tropical estuary in Northeastern Brazil. Revista Brasileira de Zoologia 20, 439-446.

Silva-Júnior, C.A.B., Mérigot, B., Lucena-Frédou, F., Ferreira, B.P., Coxey, M.S., Rezende, S.M., Frédou, T., 2016. Functional diversity of fish in tropical estuaries: A traits-based approach of communities in Pernambuco, Brazil. Estuarine, Coastal and Shelf Science 198, 413-420. doi: 10.1016/j.ecss.2016.08.030

Smith, B.N., Epstein, S., 1971. Two categories of c/c ratios for higher plants. Plant Physiology 47, 380384.

Stevens, P.W., Blewett, D.A., Poulakis, G.R., 2007. Variable habitat use by juvenile common snook, Centropomus undecimalis (Pisces: Centropomidae): Applying a life-history model in a southwest Florida estuary. Bulletin of Marine Science 80, 93-108.

Stevens, P.W, Boucek, R.E., Trotter, A.A., Ritch, J.L., Jhonson, E.R., Shea, C.P., Blewett, D.A., Rehage, J.S., 2018. Illustrating the value of cross-site comparisons: Habitat use by a large, euryhaline fish differs along a latitudinal gradient. Fisheries Research 208, 42-48. doi: 10.1016/j.fishres.2018.07.005

Syväranta, J., Lensu, A., Marjomäki, T.J., Oksanen, S., Jones, R.I., 2013. An empirical evaluation of the utility of convex hull and standard ellipse areas for assessing population niche widths from stable isotope data. PLoS One 8, 1-8. doi:10.1371/journal.pone.0056094

Van Valen, L., 1965. Morphological Variation and Width of Ecological Niche. The American Naturalist 99, 377-390. 
Vasconcelos, R.P., Henriques, S., França, S., Pasquaud, S., Cardoso, I., Laborde, M., Cabral, H.N., 2015. Global patterns and predictors of fish species richness in estuaries. Journal of Animal Ecology 84, 1331-1341. doi:10.1111/1365-2656.12372

Vasconcelos Filho, A.L., Neumann-Leitão, S., Eskinazi-Leça, E., Schwamborn, R., Oliveira, A.M.E., Paranaguá, M.N., 2003. Trophic interactions between fish and other compartment communities in a tropical estuary in Brazil as indicator of environmental quality. In: Tiezzi, E., Brebbia, C.A., Usó, J. L. (Eds.), Ecosystems and Sustainable Development IV. WIT Press, Southampton, UK, pp 173-183.

Viana, P.A., Lucena-Frédou, F., Ménard, F., Frédou, T., Ferreira, V., Lira, A.S., Le Loc’h, F., 2016. Length-weight relations of 70 species (Actinopterygii) from tropical coastal region of Pernambuco, Northeast Brazil. Acta Ichthyologica et Piscatoria 46, 271-277. doi: 10.3750/AIP2016.46.3.12

Winemiller, K.O., 1990. Spatial and temporal variation in tropical fish trophic networks. Ecological Monographs 60, 331-367.

Winemiller, K.O., Zeug, S.C., Robertson, C.R., Winemiller, B.K., Honeycutt, R.L., 2011. Food-web structure of coastal streams in Costa Rica revealed by dietary and stable isotope analyses. Journal of Tropical Ecology 27, 463-476. doi: 10.1017/S0266467411000277

Yang, Z., Wang, T., Voisin, N., Copping, A., 2015. Estuarine response to river flow and sea-level rise under future climate change and human development. Estuarine, Coastal and Shelf Science 156, 19 30. doi: 10.1016/j.ecss.2014.08.015

Young, K.A., 2001. Habitat diversity and species diversity: testing the competition hypothesis with juvenile salmonids. Oikos 95, 87-93. 


\section{Figure Captions}

Fig 1. Estuarine systems of Santa Cruz Channel (Catuama (a) and Santa Cruz (b)), Suape (c) and Sirinhaém (d) located in Pernambuco state, northeastern Brazil. Mangrove areas are shown in darker grey and sample locations on each site are represented by black dots.

Fig 2. Length frequency distributions of Centropomus undecimalis (a) and C. parallelus (b) sampled in four tropical estuaries, northeastern Brazil. Solid and dashed lines represent the size used for linear models and mean length of each species, respectively.

Fig 3. Relationship between nitrogen $\left(\delta^{15} \mathrm{~N}\right)$ and carbon $\left(\delta^{13} \mathrm{C}\right)$ isotope values and fish size (standard length) of Centropomus undecimalis (black points) and C. parallelus (grey points) sampled in four tropical estuaries, northeastern Brazil. Solid line shows significant linear regression with the shaded area representing the standard error.

Fig 4. Carbon $\left(\delta^{13} \mathrm{C}\right)$ and nitrogen $\left(\delta^{15} \mathrm{~N}\right)$ isotope ratios (mean \pm standard deviation in per mil) of snooks (Centropomus undecimalis and C. parallelus; FISH), a primary consumer (Crassostrea rhizophorae; INVTB) and sources of primary production (SOURCES) sampled in four tropical estuaries, northeastern Brazil, during dry and rainy seasons. Samples of snook species are presented with predicted $\delta^{15} \mathrm{~N}$ values. Species: 1. C. undecimalis; 2. C. parallelus; 3. C. rhizophorae; 4. POM, particulate organic matter; 5. SOM, sediment organic matter; 6. Rhizophorae mangle; 7. Ulva sp.; 8. Sargassum sp..

Fig 5. Scaled isotopic niches of Centropomus undecimalis and C. parallelus sampled in four tropical estuaries, northeastern Brazil, during dry and rainy seasons. Lines represent the corrected standard ellipses area $\left(\mathrm{SEA}_{\mathrm{C}}\right)$ for each species, with scaled predicted $\delta^{15} \mathrm{~N}$ values (see subsection 2.3 ). 
Tables

Characteristics

Estuary

\begin{tabular}{|c|c|c|c|c|}
\hline & \multicolumn{2}{|c|}{$\begin{array}{c}\text { Estuarine Complex of Santa } \\
\text { Cruz Channel }\end{array}$} & \multirow[t]{2}{*}{ Suape } & \multirow[t]{2}{*}{ Sirinhaém } \\
\hline & Catuama & Santa Cruz & & \\
\hline Type & Ria & $\mathrm{Ria}$ & Coastal lagoon & Coastal plain \\
\hline Estuary $\left(\mathrm{km}^{2}\right)^{\dagger}$ & 49.8 & 25.9 & 29.7 & 18.7 \\
\hline Vegetated area $\left(\mathrm{km}^{2}\right)^{\dagger}$ & 35.2 & 14.9 & 23.1 & 17.0 \\
\hline Water surface area $\left(\mathrm{km}^{2}\right)^{\dagger}$ & 14.6 & 10.9 & 6.6 & 1.7 \\
\hline Mean depth (m) & 7.5 & 3.0 & 3.1 & 2.6 \\
\hline Max. depth (m) & 20 & 7 & 5 & 5 \\
\hline Mouth width $(\mathrm{km})^{\dagger}$ & 1.3 & 0.5 & 0.3 & 0.4 \\
\hline Temperature $\left({ }^{\circ} \mathrm{C}, \text { mean } \pm \mathrm{SD}\right)^{\ddagger}$ & $26.62 \pm 0.79$ & $28.58 \pm 1.18$ & $27.13 \pm 1.09$ & $27.24 \pm 2.47$ \\
\hline Salinity $\left(\right.$ mean \pm SD) ${ }^{\ddagger}$ & $28.58 \pm 1.18$ & $31.16 \pm 2.94$ & $17.77 \pm 2.43$ & $9.57 \pm 3.69$ \\
\hline Activity & $\begin{array}{r}\text { Aquaculture } \\
\text { domes }\end{array}$ & $\begin{array}{l}\text { ndustrial and } \\
\text { waste }\end{array}$ & $\begin{array}{l}\text { Industrial harbour, } \\
\text { industrial and } \\
\text { agriculture waste }\end{array}$ & $\begin{array}{l}\text { Industrial and } \\
\text { domestic waste }\end{array}$ \\
\hline Reference & $\begin{array}{r}\text { Medeiros an } \\
\text { Medeiros et al., } \\
\text { al., 2010; }\end{array}$ & $\begin{array}{l}\text { jerfve, 1993; } \\
\text { 01; Guimarães et } \\
\text { a et al., 2011 }\end{array}$ & $\begin{array}{l}\text { CPRH, 2001; Borges, } \\
\text { 2011; Silva et al. } 2011\end{array}$ & $\begin{array}{l}\text { CPRH, 2001; Silva, } \\
\text { 2009; Silva et al., } 2011\end{array}$ \\
\hline
\end{tabular}

Table 1 Summary of morphological characteristics and anthropogenic activities of four estuaries along the coast of Pernambuco, Brazil. 


\begin{tabular}{|c|c|c|c|c|c|c|c|c|c|c|c|}
\hline \multirow[b]{2}{*}{ Estuary } & \multirow[b]{2}{*}{ Species } & \multicolumn{10}{|c|}{ Season } \\
\hline & & $\mathrm{n}$ & $\mathrm{SL}(\mathrm{mm})$ & $\delta^{13} \mathrm{C}(\% \circ)$ & $\delta^{15} \mathrm{~N}(\% \circ)$ & Pred. $\delta^{15} \mathrm{~N}(\% o)$ & $\mathrm{n}$ & $\mathrm{SL}(\mathrm{mm})$ & $\delta^{13} \mathrm{C}(\% \circ)$ & $\delta^{15} \mathrm{~N}(\% \circ)$ & Pred. $\delta^{15} \mathrm{~N}(\% \circ)$ \\
\hline \multirow[t]{2}{*}{$\begin{array}{l}\text { Catuama } \\
\text { (CAT) }\end{array}$} & C. undecimalis & 6 & $\begin{array}{c}202 \pm 36 \\
{[158-244]}\end{array}$ & $\begin{array}{c}-17.10 \pm 2.51 \\
{[-21.62--14.74]}\end{array}$ & $\begin{array}{c}10.30 \pm 0.96 \\
{[8.80-11.67]}\end{array}$ & $\begin{array}{c}10.27 \pm 0.81 \\
{[9.10-11.37]}\end{array}$ & 9 & $\begin{array}{c}199 \pm 27 \\
{[149-231]}\end{array}$ & $\begin{array}{c}-20.09 \pm 2.30 \\
{[-23.51--14.92]}\end{array}$ & $\begin{array}{c}10.07 \pm 0.51 \\
{[9.44-10.95]}\end{array}$ & $\begin{array}{c}10.08 \pm 0.48 \\
{[9.32-10.72]}\end{array}$ \\
\hline & C. parallelus & 8 & $\begin{array}{c}91 \pm 35 \\
{[70-178]}\end{array}$ & $\begin{array}{c}-20.06 \pm 0.92 \\
{[-21.03--18.08]}\end{array}$ & $\begin{array}{c}9.55 \pm 0.56 \\
{[8.88-10.29]}\end{array}$ & $\begin{array}{c}10.47 \pm 0.73 \\
{[9.15-11.25]}\end{array}$ & 8 & $\begin{array}{c}140 \pm 29 \\
{[90-176]}\end{array}$ & $\begin{array}{c}-19.79 \pm 1.61 \\
{[-21.78--16.47]}\end{array}$ & $\begin{array}{c}9.91 \pm 0.92 \\
{[8.98-11.47]}\end{array}$ & $\begin{array}{c}10.40 \pm 0.86 \\
{[9.40-11.84]}\end{array}$ \\
\hline \multirow[t]{2}{*}{$\begin{array}{l}\text { Santa Cruz } \\
\text { (STC) }\end{array}$} & C. undecimalis & 10 & $\begin{array}{c}227 \pm 21 \\
{[204-257]}\end{array}$ & $\begin{array}{c}-19.03 \pm 2.00 \\
{[-22.81--16.74]}\end{array}$ & $\begin{array}{c}10.89 \pm 0.95 \\
{[9.54-12.36]}\end{array}$ & $\begin{array}{c}10.67 \pm 0.92 \\
{[9.48-12.21]}\end{array}$ & & $\begin{array}{c}310 \pm 102 \\
{[69-392]}\end{array}$ & $\begin{array}{c}-18.95 \pm 3.32 \\
{[-24.31--14.94]}\end{array}$ & $\begin{array}{c}10.94 \pm 1.88 \\
{[6.94-12.77]}\end{array}$ & $\begin{array}{c}10.02 \pm 1.36 \\
{[8.04-11.65]}\end{array}$ \\
\hline & C. parallelus & 5 & $\begin{array}{c}239 \pm 26 \\
{[205-273]}\end{array}$ & $\begin{array}{c}-20.83 \pm 3.97 \\
{[-24.90--14.22]}\end{array}$ & $\begin{array}{c}12.23 \pm 1.25 \\
{[10.60-13.64]}\end{array}$ & $\begin{array}{c}11.90 \pm 1.09 \\
{[10.41-13.22]}\end{array}$ & 8 & $\begin{array}{c}165 \pm 23 \\
{[132-192]}\end{array}$ & $\begin{array}{c}-19.39 \pm 1.73 \\
{[-22.40--17.72]}\end{array}$ & $\begin{array}{c}11.05 \pm 1.12 \\
{[9.48-13.15]}\end{array}$ & $\begin{array}{c}11.35 \pm 1.08 \\
{[9.75-13.31]}\end{array}$ \\
\hline \multirow[t]{2}{*}{$\begin{array}{l}\text { Suape } \\
\text { (SUA) }\end{array}$} & C. undecimalis & 7 & $\begin{array}{c}250 \pm 39 \\
{[213-323]}\end{array}$ & $\begin{array}{c}-20.20 \pm 0.72 \\
{[-21.31--19.39]}\end{array}$ & $\begin{array}{c}11.86 \pm 0.43 \\
{[11.32-12.50]}\end{array}$ & $\begin{array}{c}11.43 \pm 0.15 \\
{[11.21-11.65]}\end{array}$ & 3 & $\begin{array}{c}169 \pm 69 \\
{[94-230]}\end{array}$ & $\begin{array}{c}-19.28 \pm 0.62 \\
{[-19.80--18.60]}\end{array}$ & $\begin{array}{c}10.88 \pm 1.02 \\
{[9.74-11.72]}\end{array}$ & $\begin{array}{c}11.13 \pm 0.44 \\
{[10.63-11.47]}\end{array}$ \\
\hline & C. parallelus & 14 & $\begin{array}{c}175 \pm 61 \\
{[57-250]}\end{array}$ & $\begin{array}{c}-20.06 \pm 1.54 \\
{[-24.85--18.71]}\end{array}$ & $\begin{array}{c}10.27 \pm 0.79 \\
{[8.47-11.50]}\end{array}$ & $\begin{array}{c}10.48 \pm 0.76 \\
{[8.62-11.56]}\end{array}$ & 11 & $\begin{array}{c}132 \pm 23 \\
{[87-167]}\end{array}$ & $\begin{array}{c}-19.88 \pm 1.72 \\
{[-22.70--16.50]}\end{array}$ & $\begin{array}{c}9.52 \pm 0.38 \\
{[8.65-9.98]}\end{array}$ & $\begin{array}{c}10.08 \pm 0.38 \\
{[9.19-10.40]}\end{array}$ \\
\hline \multirow[t]{2}{*}{$\begin{array}{l}\text { Sirinhaém } \\
\text { (SIR) }\end{array}$} & C. undecimalis & 9 & $\begin{array}{c}208 \pm 16 \\
{[184-243]}\end{array}$ & $\begin{array}{c}-21.58 \pm 1.16 \\
{[-23 ; 48--20.18]}\end{array}$ & $\begin{array}{c}10.36 \pm 0.23 \\
{[9.97-10.71]}\end{array}$ & $\begin{array}{c}10.29 \pm 0.17 \\
{[9.91-10.49]}\end{array}$ & 10 & $\begin{array}{c}196 \pm 68 \\
{[150-386]}\end{array}$ & $\begin{array}{c}-22.09 \pm 0.88 \\
{[-23.34--20.79]}\end{array}$ & $\begin{array}{c}9.62 \pm 0.52 \\
{[8.77-10.66]}\end{array}$ & $\begin{array}{c}9.65 \pm 0.42 \\
{[8.93-10.27]}\end{array}$ \\
\hline & C. parallelus & 10 & $\begin{array}{c}199 \pm 49 \\
{[119-289]}\end{array}$ & $\begin{array}{c}-20.25 \pm 2.31 \\
{[-25.38--16.62]}\end{array}$ & $\begin{array}{c}11.14 \pm 0.61 \\
{[10.24-12.10]}\end{array}$ & $\begin{array}{c}11.14 \pm 0.61 \\
{[10.19-12.16]}\end{array}$ & 12 & $\begin{array}{c}212 \pm 43 \\
{[151-290]}\end{array}$ & $\begin{array}{c}-22.37 \pm 0.90 \\
{[-23.43--20.13]}\end{array}$ & $\begin{array}{c}10.17 \pm 0.35 \\
{[9.64-10.77]}\end{array}$ & $\begin{array}{c}10.06 \pm 0.30 \\
{[9.47-10.55]}\end{array}$ \\
\hline
\end{tabular}

Table 2 Number of samples (n), mean fish standard length (SL; \pm S.D.), isotopic means $\left( \pm\right.$ S.D.) of carbon $\left(\delta^{13} \mathrm{C}\right)$, nitrogen $\left(\delta^{15} \mathrm{~N}\right)$ and predicted $\delta^{15} \mathrm{~N}$ at $200 \mathrm{~mm}$ SL $($ see subsection 2.3) ( \pm S.D.) of Centropomus undecimalis and C. parallelus, during dry and rainy seasons, sampled in four tropical estuaries, northeastern Brazil. Minimum and maximum values of each variable are shown in brackets 


\begin{tabular}{|c|c|c|c|c|c|c|}
\hline \multirow{3}{*}{ Species } & \multicolumn{4}{|c|}{ Season } & \multirow[b]{3}{*}{$\mathrm{n}$} & \multirow[b]{3}{*}{$\mathrm{TP}_{\mathrm{SCA}}$} \\
\hline & \multicolumn{2}{|c|}{ Dry } & \multicolumn{2}{|c|}{ Rainy } & & \\
\hline & $\mathrm{TP}_{\mathrm{SIA} 1}$ & $\mathrm{TP}_{\mathrm{SIA} 2}$ & $\mathrm{TP}_{\mathrm{SIA} 1}$ & $\mathrm{TP}_{\mathrm{SIA} 2}$ & & \\
\hline \multicolumn{7}{|l|}{ Catuama (CAT) } \\
\hline C. undecimalis & $\begin{array}{c}3.15 \\
{[2.32-5.18]}\end{array}$ & $\begin{array}{c}3.83 \\
{[3.07-5.19]}\end{array}$ & $\begin{array}{c}2.74 \\
{[2.45-3.37]}\end{array}$ & $\begin{array}{c}2.97 \\
{[2.35-4.01]}\end{array}$ & & \\
\hline C. parallelus & $\begin{array}{c}3.23 \\
{[2.41-5.47]}\end{array}$ & $\begin{array}{c}3.93 \\
{[3.21-5.25]}\end{array}$ & $\begin{array}{c}2.91 \\
{[2.46-3.94]}\end{array}$ & $\begin{array}{c}3.12 \\
{[2.42-4.25]}\end{array}$ & & \\
\hline \multicolumn{7}{|l|}{ Santa Cruz (STC) } \\
\hline C. undecimalis & $\begin{array}{c}3.26 \\
{[2.75-4.10]}\end{array}$ & $\begin{array}{c}3.14 \\
{[2.34-4.36]}\end{array}$ & $\begin{array}{c}2.73 \\
{[2.18-3.68]}\end{array}$ & $\begin{array}{c}3.31 \\
{[2.49-4.61]}\end{array}$ & 8 & 3.45 \\
\hline C. parallelus & $\begin{array}{c}3.79 \\
{[2.92-5.09]}\end{array}$ & $\begin{array}{c}3.66 \\
{[2.61-5.28]}\end{array}$ & $\begin{array}{c}3.15 \\
{[2.70-4.32]}\end{array}$ & $\begin{array}{c}3.88 \\
{[3.08-5.31]}\end{array}$ & 10 & 3.47 \\
\hline \multicolumn{7}{|l|}{ Suape (SUA) } \\
\hline C. undecimalis & $\begin{array}{c}3.85 \\
{[3.08-5.06]}\end{array}$ & $\begin{array}{c}3.43 \\
{[2.39-4.86]}\end{array}$ & $\begin{array}{c}3.35 \\
{[2.42-5.60]}\end{array}$ & $\begin{array}{c}3.87 \\
{[2.61-6.03]}\end{array}$ & & \\
\hline C. parallelus & $\begin{array}{c}3.46 \\
{[2.80-4.61]}\end{array}$ & $\begin{array}{c}2.96 \\
{[1.99-4.38]}\end{array}$ & $\begin{array}{c}2.89 \\
{[2.41-3.83]}\end{array}$ & $\begin{array}{c}3.45 \\
{[2.69-4.70]}\end{array}$ & & \\
\hline \multicolumn{7}{|l|}{ Sirinhaém (SIR) } \\
\hline C. undecimalis & $\begin{array}{c}3.43 \\
{[2.57-6.57]}\end{array}$ & $\begin{array}{c}3.56 \\
{[2.71-5.03]}\end{array}$ & $\begin{array}{c}2.71 \\
{[2.31-3.59]}\end{array}$ & $\begin{array}{c}3.41 \\
{[2.73-4.59]}\end{array}$ & 45 & 3.55 \\
\hline C. parallelus & $\begin{array}{c}3.80 \\
{[2.79-5.71]} \\
\end{array}$ & $\begin{array}{c}3.97 \\
{[3.01-5.49]} \\
\end{array}$ & $\begin{array}{c}2.89 \\
{[2.44-3.90]}\end{array}$ & $\begin{array}{c}3.60 \\
{[2.90-4.81]} \\
\end{array}$ & 30 & 3.54 \\
\hline
\end{tabular}

Table 3: Trophic position estimates with stable isotopes $\left(\mathrm{TP}_{\mathrm{SIA}}\right)$ and stomach content analysis $\left(\mathrm{TP}_{\mathrm{SCA}}\right)$ of from two sympatric estuarine fishes (Centropomus undecimalis and C. parallelus) at four tropical estuaries, northeastern Brazil. $\mathrm{TP}_{\mathrm{SIA}}$ is presented as the mode of Bayesian model results with $95 \%$ credibility intervals shown in brackets. $\mathrm{TP}_{\mathrm{SIA}}$ was estimated using two distinct baselines: a long-lived primary consumer $\left(\mathrm{TP}_{\mathrm{SIA} 1}\right)$; and all available basal sources at each site $\left(\mathrm{TP}_{\mathrm{SIA} 2}\right)$. 


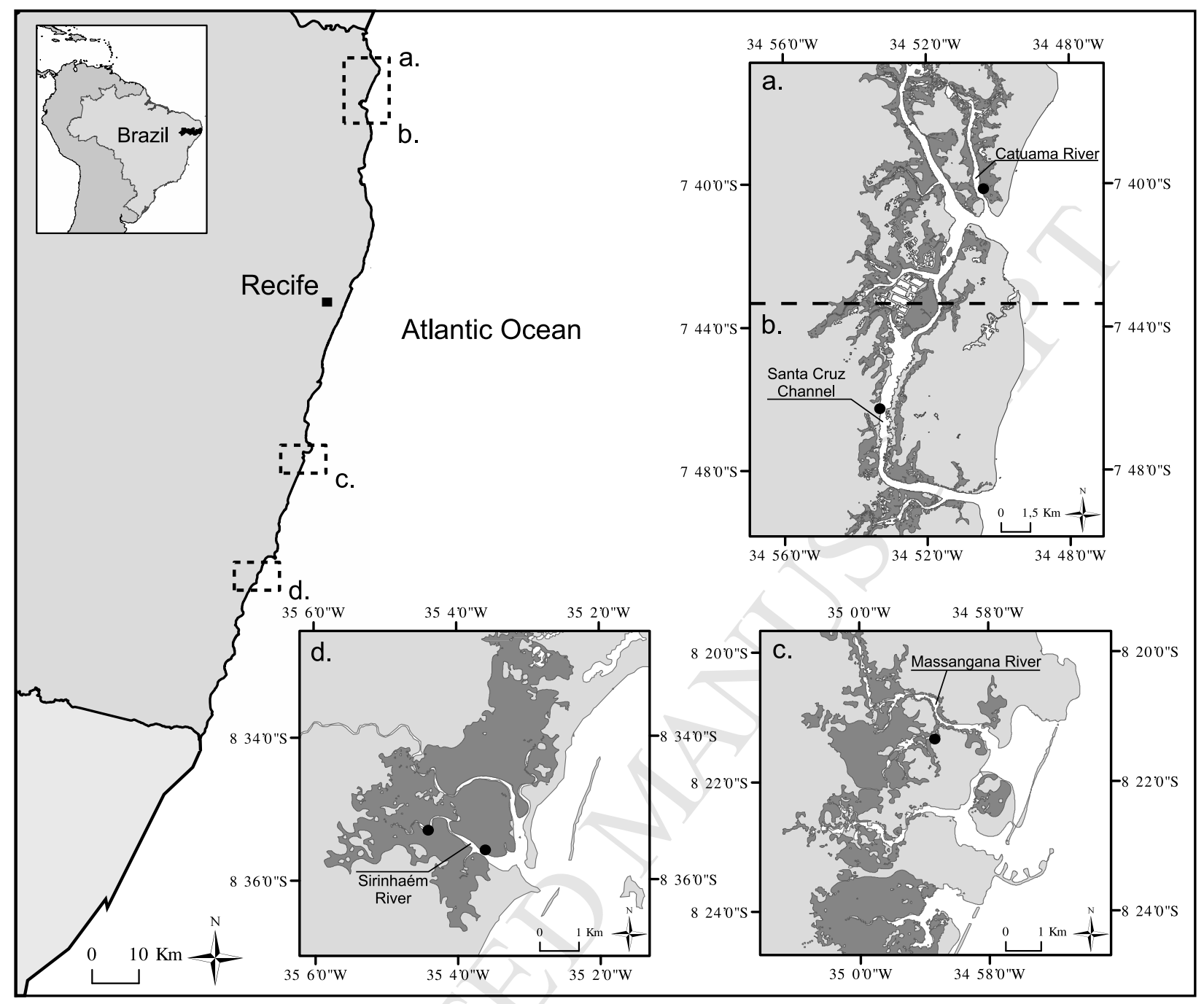




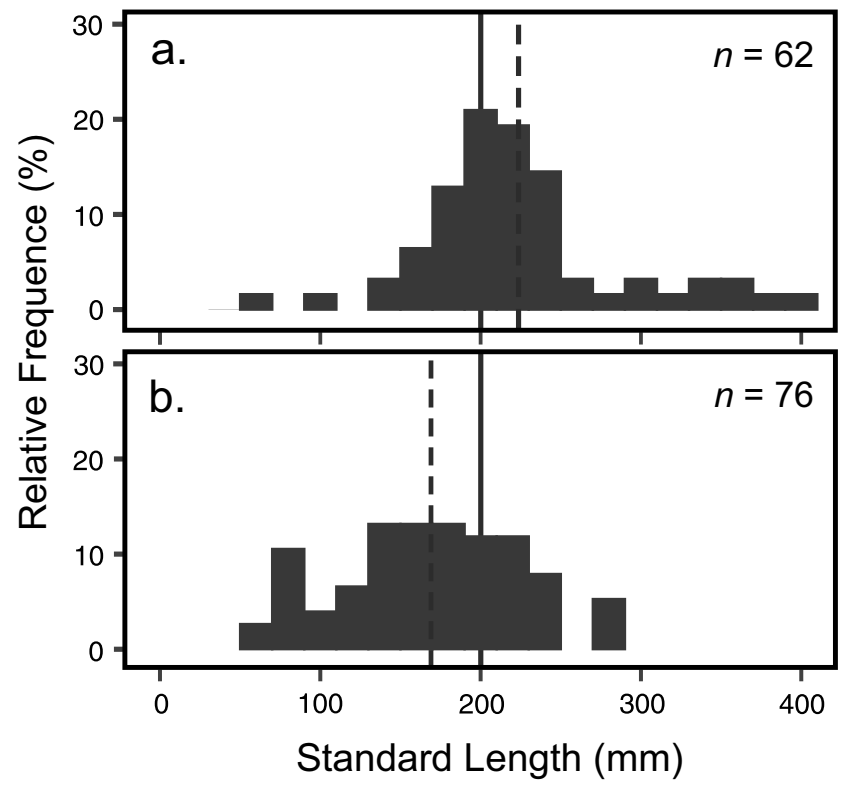




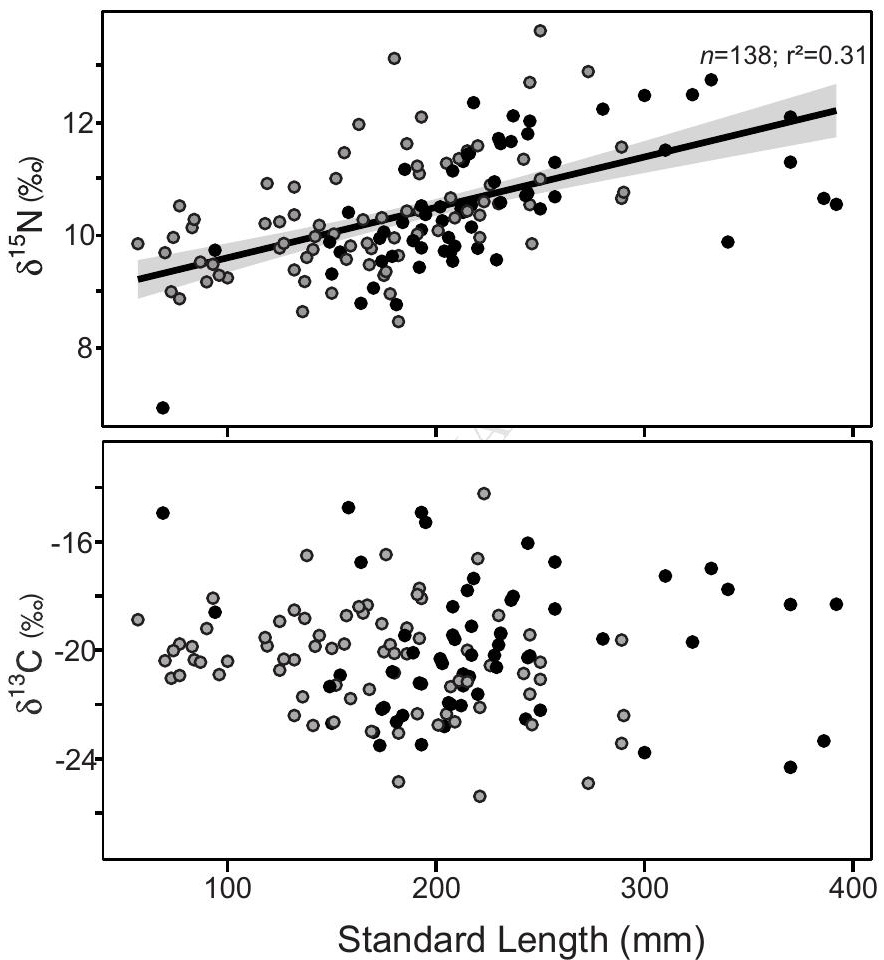




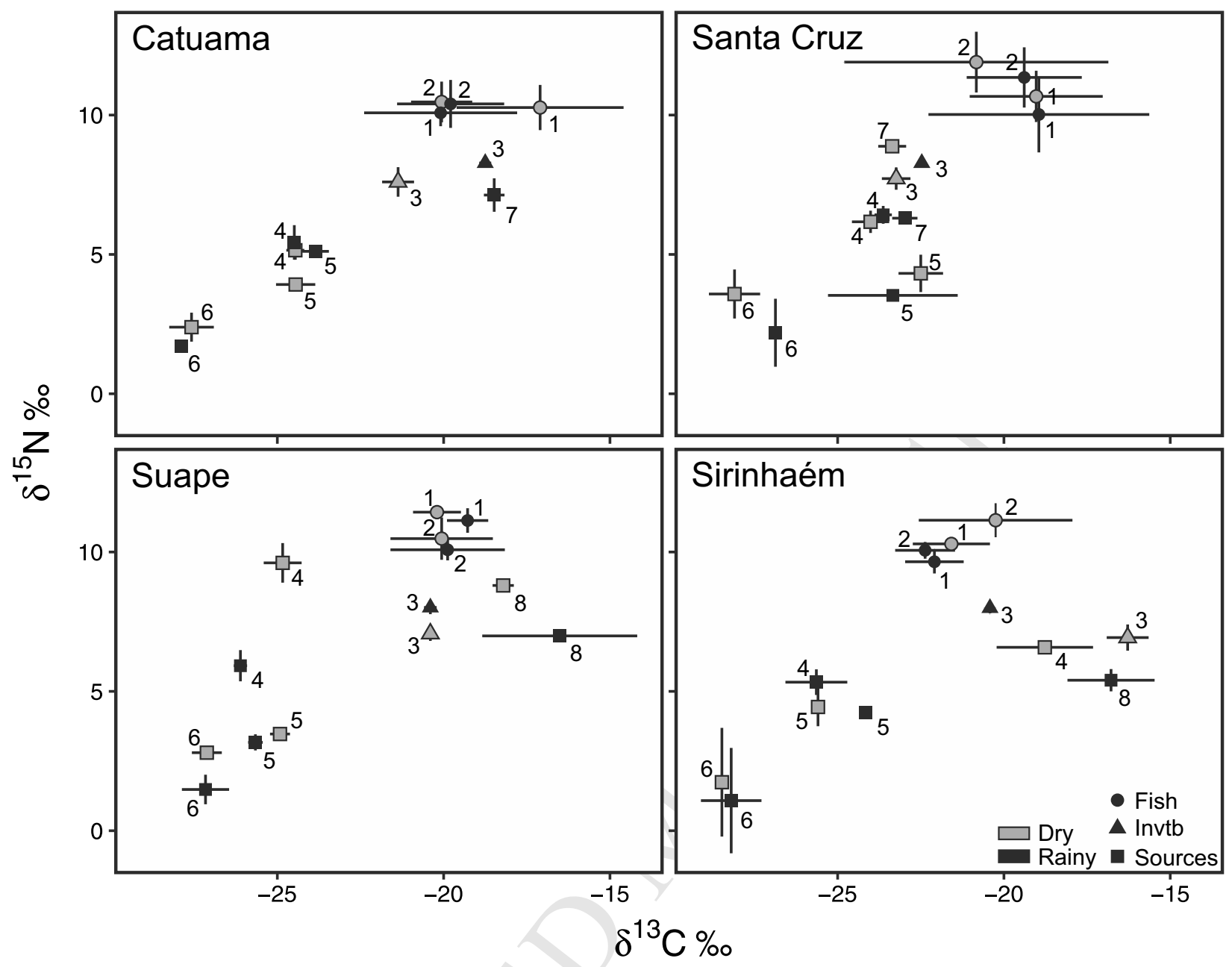




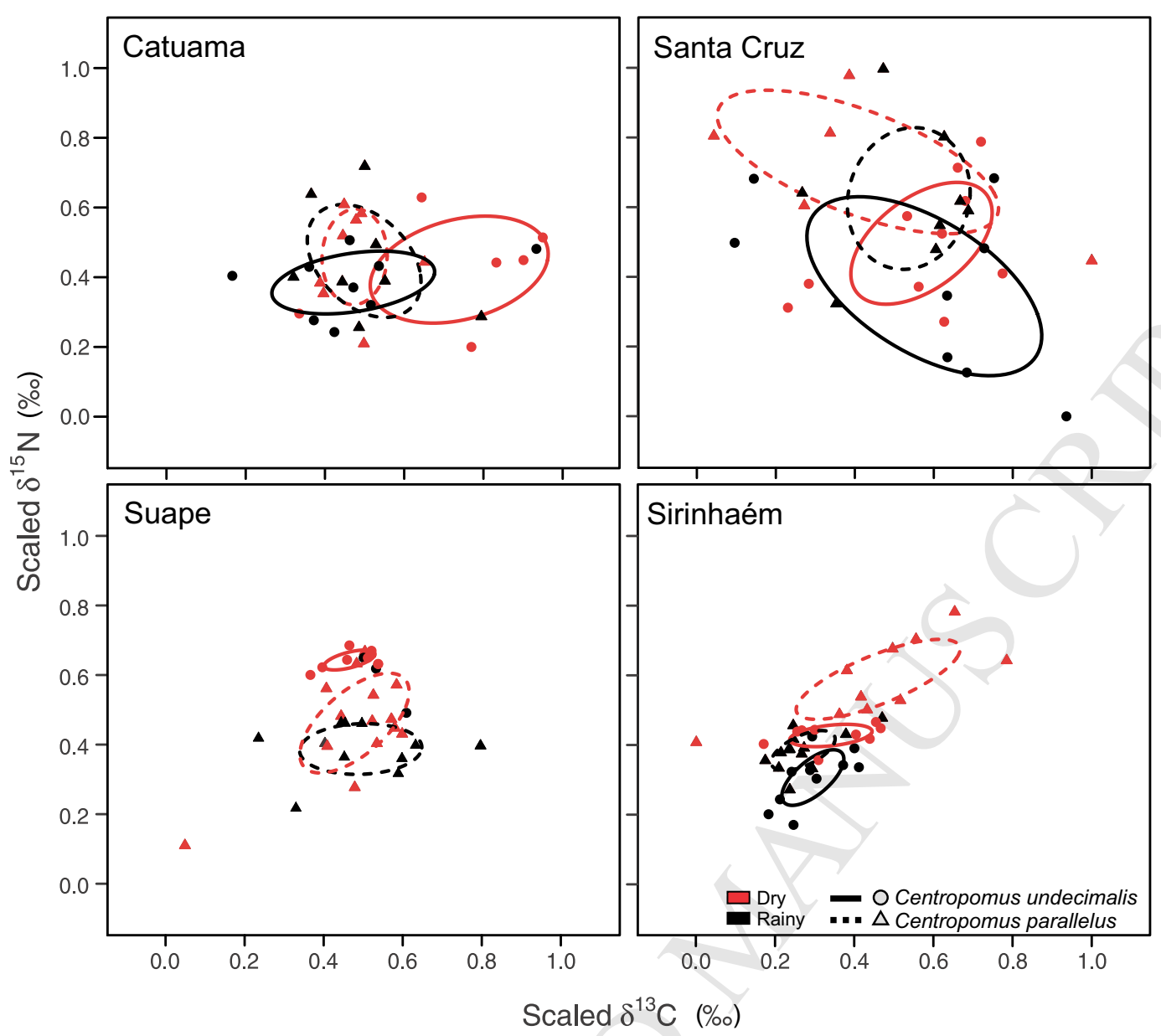




\section{Highlights}

- $\delta^{13} \mathrm{C}$ and $\delta^{15} \mathrm{~N}$ of two Centropomidae were investigated in four estuaries in Brazil

- Juveniles of Centropomus undecimalis and C. parallelus have close isotopic niches

- Trophic overlaps were more pronounced in large estuaries

- Resource partitioning process might reflects the resource availability in estuaries 